\title{
Quantifying thresholds of barrier geomorphic change in a cross-shore sediment-partitioning model
}

\author{
Daniel J. Ciarletta ${ }^{1}$, Jennifer L. Miselis ${ }^{1}$, Justin L. Shawler ${ }^{2}$, and Christopher J. Hein ${ }^{2}$ \\ ${ }^{1}$ US Geological Survey, St. Petersburg Coastal and Marine Science Center, \\ 600 4th St. S, St. Petersburg, Florida, 33701, USA \\ ${ }^{2}$ Virginia Institute of Marine Science, William \& Mary, P.O. Box 1346, Gloucester Point, Virginia, 23062, USA
}

Correspondence: Daniel J. Ciarletta (dciarletta@usgs.gov)

Received: 21 October 2020 - Discussion started: 21 November 2020

Revised: 2 February 2021 - Accepted: 4 February 2021 - Published: 17 March 2021

\begin{abstract}
Barrier coasts, including barrier islands, beach-ridge plains, and associated landforms, can assume a broad spectrum of morphologies over multi-decadal scales that reflect conditions of sediment availability, accommodation, and relative sea-level rise. However, the quantitative thresholds of these controls on barriersystem behavior remain largely unexplored, even as modern sea-level rise and anthropogenic modification of sediment availability increasingly reshape the world's sandy coastlines. In this study, we conceptualize barrier coasts as sediment-partitioning frameworks, distributing sand delivered from the shoreface to the subaqueous and subaerial components of the coastal system. Using an idealized morphodynamic model, we explore thresholds of behavioral and morphologic change over decadal to centennial timescales, simulating barrier evolution within quasi-stratigraphic morphological cross sections. Our results indicate a wide diversity of barrier behaviors can be explained by the balance of fluxes delivered to the beach vs. the dune or backbarrier, including previously understudied forms of transgression that allow the subaerial system to continue accumulating sediment during landward migration. Most importantly, our results show that barrier state transitions between progradation, crossshore amalgamation, aggradation, and transgression are controlled largely through balances within a narrow range of relative sea-level rise and sediment flux. This suggests that, in the face of rising sea levels, subtle changes in sediment fluxes could result in significant changes in barrier morphology. We also demonstrate that modeled barriers with reduced vertical sediment accommodation are highly sensitive to the magnitude and direction of shoreface fluxes. Therefore, natural barriers with limited sediment accommodation could allow for exploration of the future effects of sea-level rise and changing flux magnitudes over a period of years as opposed to the decades required for similar responses in sediment-rich barrier systems. Finally, because our model creates stratigraphy generated under different input parameters, we propose that it could be used in combination with stratigraphic data to hindcast the sensitivity of existing barriers and infer changes in prehistoric morphology, which we anticipate will provide a baseline to assess the reliability of forward modeling predictions.
\end{abstract}

1

\section{Introduction}

Despite historically unprecedented rates of modern sea-level rise (SLR) and regional-scale coastal interventions affecting alongshore sediment redistribution, impacts on the morphology of barrier coasts over decadal to centennial scales remain loosely quantified. This information gap, resulting from an absence of both data and models with appropriate temporal resolution, contributes to a lack of long-term coastal management policy (McNamara and Lazarus, 2018), and in some cases could lead to either overestimation or underestimation of decadal-scale coastal change. Especially in unmodified and semi-natural barrier systems, the shoreface, beach, and backbarrier are likely coupled through cross-shore and alongshore sediment transport pathways over multi-decadal timescales (Ashton and Lorenzo-Trueba, 2018), suggesting 
that simple models of sandy shoreline retreat that do not account for such interactions may significantly depart from real-world rates of transgression (Cooper et al., 2020).

Historically, the modeling gap has evolved out of a tendency to view geomorphic change as a function of processscale and/or structural drivers. In the former, individual processes on the order of days to weeks become the dominant agents of morphologic change. These include high-water and storm events (Cohn et al., 2019), as well as bar-welding events (Aagaard et al., 2004) and other processes that affect or are mediated by the surf and intertidal zones. In the latter, geologic controls over broad spatiotemporal domains (hundreds to thousands of years and tens of kilometers), such as antecedent slope (Masetti et al., 2008; Murray and Moore, 2018; Shawler et al., 2021) and internal system dynamics play a larger role. Internal dynamics include, for example, lags in the response of the shoreface to landward-directed overwash (Lorenzo-Trueba and Ashton, 2014; Ashton and Lorenzo-Trueba, 2018), which may also amplify or dampen the long-term retreat response of a barrier system to changes in SLR (Ciarletta et al., 2019a).

At the decadal to centennial scale, underlying substrate sedimentology and shoreface sediment availability are among the most significant drivers of morphological change (Psuty, 2008; Brenner et al., 2015; Cooper et al., 2018). Similarly, sediment budgets alter barrier landscapes on scales of meters to kilometers over years to decades, reflecting the sum of numerous events (e.g., storms, changes in wind and wave direction, etc.) occurring over sub-annual timeframes (Sherman, 1995). Subsequently, the construction of a mesoscale model to examine sediment availability requires a morphodynamic framework or a model that utilizes sediment fluxes to drive changes in morphology. However, such a model need not be event-based to approximate the net result of fluxdriven changes in time, allowing for a reduced-complexity simulation (French et al., 2016). This is consistent with the hierarchal view of natural systems by Werner et al. (2003), which considers characteristic timescales of landscape selforganization from processes occurring over shorter time intervals. The concept is particularly suited to mesoscale modeling of barrier evolution, where emergent morphology is at least partly understood from observational and historical records (Psuty, 2008; Psuty and Silveira, 2013) but cannot be easily driven by linear relationships alone (Cooper et al., 2018). Furthermore, by idealizing the geometry of barrier systems, it is possible to partition sediment volume within a simple deterministic framework, relying on geometric and algebraic relationships to shape the morphology of the system as a function of not just sediment fluxes but also changes in other external forcing (e.g., changing accommodation due to SLR). A similar type of modeling has been accomplished by McNamara and Werner (2008a, b), who constructed a geometrically simplified barrier model with partitioned sediment distribution driven by beach replenishment tied to human development.
Working toward understanding and modeling barrier behavior over decades to centuries, we use a reducedcomplexity morphodynamic model to evaluate the crossshore morphological and behavioral response of a barrier system given (1) variable rates of sediment delivery and partitioning, (2) sea-level rise rate, and (3) sandy-substructure accommodation - the vertical depth to which sediment can fill or erode to affect extension or retreat of the shoreline. The primary objective is to explore how combinations of these parameters beget different barrier states, including transgression, aggradation, and progradation. Ultimately, our goal is to understand how changes in sediment fluxes to and from the shoreface and dune, resulting from either SLR or variations in vertical accommodation, impact the magnitude and timing of barrier state transitions. A record of the magnitude and directionality of changes in past sediment budgets could be reconstructed for real-world barriers with this and similar model frameworks to reveal the impact of such state transitions on modern and future barrier behavior. Combined with available historical data from modern barriers, which provide limited control points to verify morphological evolution (Cooper et al., 2018), our approach allows us to quantify, to the first order, the sediment flux and partitioning conditions driving a diverse spectrum of decadal and centennial changes in barrier morphology. We can also potentially capture transitions that may not have been observed or inferred in historical records.

\section{Background}

At the mesoscale (tens to hundreds of years), historical records have been instrumental in most studies of real-world barriers, but these records are usually temporally incomplete or only focus on one moving boundary within the barrier system (e.g., shoreline; Cooper et al., 2018). Despite these deficiencies, the behavior and morphology of barriers as a function of sediment input at this scale have been qualitatively described by geomorphologists (Psuty, 2008; Psuty and Silveira, 2013). While such descriptions lack quantitative thresholds of geomorphic change - especially in combination with external controls (e.g., rate of sea-level rise) and geologic controls (e.g., sediment accommodation, substrate lithology; see Shawler et al., 2021) - they provide a strong foundation to construct a mesoscale model framework capable of simulating barrier morphology.

Psuty (2008) outlines a conceptual model of sediment availability-driven morphological response in barriers where subaerial development is related to directionality and magnitude of shoreline migration (Fig. 1). An increasingly positive sediment budget (sediment budget $>$ accommodation creation) should lead to rapid progradation of the beach and result in a succession of preserved foredunes formed in the wake of the receding shoreline. Coincidently, growth in net sediment budget should also lead to the formation of progres- 


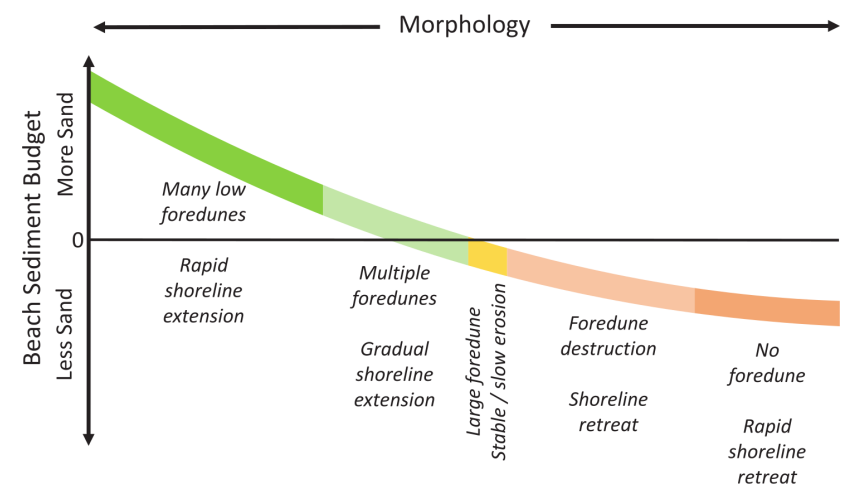

Figure 1. Conceptual morphological continuum, depicting the subaerial characteristics of a barrier in response change in beach sediment budget. Modified from Psuty (2008). Used with permission from Springer Nature.

sively diminutive foredune ridges, which become smaller due to the more limited time available for sediment accumulation in a single ridge. Conversely, an increasingly negative budget should result in more rapid transgression and a loss of foredune volume owing to erosion and a lack of time to accumulate new sediment as the shoreline migrates landward into relict ridges. The Psuty (2008) continuum additionally identifies an equilibrium state where the beach sediment budget approaches zero. When this occurs, the shoreline position stabilizes, allowing the gradual addition of sediment to the active foredune. In such cases, the barrier can reach maximum subaerial development, potentially forming very large foredunes.

Motivated by the concepts of Psuty (2008), Ciarletta et al. (2019b) developed a two-step, cross-shore sedimentpartitioning model in which shoreface fluxes to the beach drive shoreline progradation, while foredune fluxes control the transport of sand from beach to dune. Within this framework, increasing accommodation from SLR removes volume from the subaerial system and forces erosion of the shoreline. Foredune volume is stored in an idealized, triangular profile, and the initiation of an incipient foredune ridge as the shoreline progrades is captured by a critical ridge spacing (Ciarletta et al., 2019b). By modulating shoreface sediment fluxes, it is possible to affect changes in foredune size, approximating the response of foredunes as observed in nature at various sites around the world (e.g., Bristow and Pucillo, 2006; Nooren et al., 2017; Oliver et al., 2019). Moreover, by testing different combinations of shoreface and foredune flux magnitudes and comparing them to real-world ridge heights, volumes, and shoreline positions, it is possible to quantify past changes in the sediment budget (Ciarletta et al., 2019b).

Though a significant first step in reproducing decadalcentennial coastal behavior, the earlier model focused specifically on prograding barrier systems, ignoring not only transgression but also the role of dynamics associated with the backbarrier stratigraphy of barrier islands (Ciarletta et al., 2019b). It is well documented at places like Fire Island, New York, that backbarrier strata beneath the modern island contain preserved beach, overwash, and marsh facies (Sirkin, 1972; Leatherman, 1985), indicating the barrier has both migrated and changed its width through time. Additionally, Raff et al. (2018) and Shawler et al. (2019) document marsh migration onto the bayside and low-lying interior of formerly progradational barrier islands, indicating a relationship between barrier width and backbarrier drowning, such that increasing island width restricts the flow of sediment to the backbarrier, thereby increasing passive interior flooding from sea-level rise. This suggests that comparing the modeled backbarrier-marsh interface through time to stratigraphic information from real-world barriers could yield insights into the sediment flux conditions at the shoreline, even if past shoreline geometries are not fully recorded in the geological record.

The inclusion of transgression within an upgraded sediment-partitioning model could also allow for exploration of the full spectrum of barrier responses to changing sediment supply (Psuty, 2008) and perhaps barrier behaviors not well-described by previous conceptual models. For instance, despite the suggestion that rapid transgression ensures the cessation of dune maintenance (Psuty, 2008), sandy beaches and barriers exist that maintain both rapidly eroding shores and very large ( $>10 \mathrm{~m}$ height) foredunes. An active, extreme example of such a system includes part of the Indiana Dunes, along the southeastern shore of Lake Michigan. The largest dune in this system, Mount Baldy, is $36 \mathrm{~m}$ tall, more than half a kilometer long, and $250 \mathrm{~m}$ wide (Kilibarda and Shillinglaw, 2015); by some measures it meets the definition of an aeolian megadune (Pye and Tsoar, 2009). Over 80 years, Mount Baldy migrated $135 \mathrm{~m}$ inland, while the corresponding lake shoreline eroded $98 \mathrm{~m}$ (Kilibarda and Shillinglaw, 2015). Additional instances of relict (but active in the last $2 \mathrm{kyr}$ ) coastal megadunes occur along the East Coast of the United States, including the Savage Neck Dunes along the Chesapeake Bay side of the Eastern Shore of Virginia (Davis, 2020; Fig. 2) and Jockey's Ridge and other large backbarrier dunes in the Outer Banks of North Carolina (Havholm et al., 2004). A combination of active and relict coastal megadunes and transgressive dunefields can also be found throughout the world, sometimes in distinct sets of sand bodies and ridges occurring over wide areas, such as along the barriers of the Rio Grande do Sul and Santa Catarina coasts of Brazil (Dillenburg et al., 2006; Vintem et al., 2006; Hesp et al., 2009). A model framework that accounted for transgression could explore the flux balances required to maintain these natural features, which we hypothesize could result from beach-to-dune fluxes greatly exceeding sediment delivery to the beach.

Finally, a morphodynamic model able to represent progradational, transgressive, and transitional behavioral and morphologic states could be used to assess the sensitivity of barriers - including beach- and dune-ridge plains, spits, tombolos, and different types of embayed barriers, in addition to 


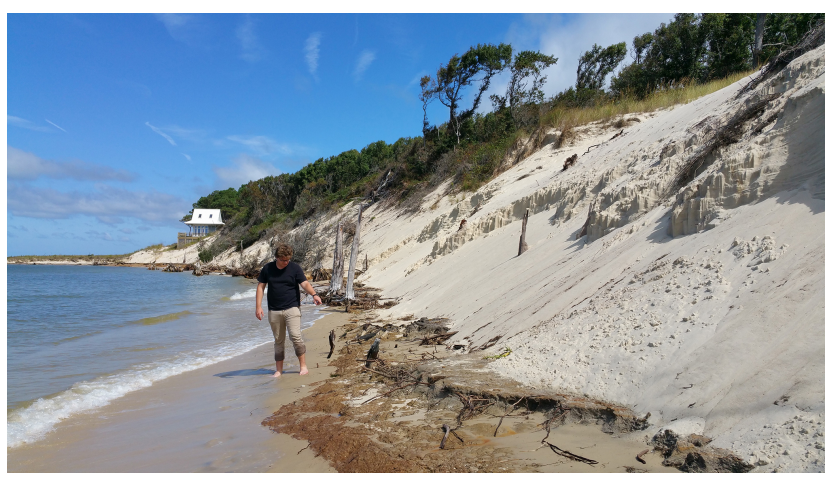

Figure 2. Justin L. Shawler inspects an erosional scarp in the Savage Neck Dunes, near Cape Charles, Virginia. Modern shoreline transgression has exposed portions of the basal terrestrial surface over which the dune system migrated, revealing the remnants of a late Holocene coastal forest buried by windblown sand. Radiocarbon dating of woody debris in the basal surface suggests dune building persisted until several hundred years ago (Davis, 2020). Image by Daniel J. Ciarletta.

barrier islands - to changes in sediment availability under a range of different environmental and geologic forcing conditions. At the mesoscale, changes in vertical accommodation driven by the rate of sea-level rise and variations in antecedent geomorphology are suggested to play a major role in barrier response (Cooper et al., 2018; Shawler et al., 2021). Moreover, sandy-substructure accommodation (the vertical space needed to be filled or eroded to invoke shoreline migration over decadal scales) differs across the globe due to both local geology and available wave energy. In some cases, vertical accommodation is solely a function of antecedent geology, where consolidated sediment and bedrock interfaces define the seaward transgressive surface of the shoreface. In other systems with unconsolidated sediments, the depth of the shoreface available to be filled is a more a function of wave climate and uppermost shoreface lithology. Combinations of these influences are possible, which suggests the baseline sensitivity of barriers to sediment input and loss magnitudes varies considerably. For example, modern barrier islands along the US Gulf and Atlantic coasts feature accommodation depths on the order of 4-6 m (e.g., Parramore and Cedar Islands in Virginia - Shawler et al., 2019, Raff et al., 2018; Brigantine Island, New Jersey - Shawler et al., 2021; Fire Island, New York - Schubert, 2010, Leatherman, 1985) to less than $3 \mathrm{~m}$ (western central Florida - Locker et al., 2001, 2002a-d). Interestingly, the barrier islands in western central Florida are considered to be among the most morphologically variable in the world and are prone to rapid change (Davis and Barnard, 2003). Adjusting accommodation in a morphodynamic model would allow us to test the influence of this factor on barrier response sensitivity and explore how coincident changes in sediment flux magnitudes drive transitions between progradation and transgression. Such an approach
Table 1. State variables for the Subaerial Barrier Sediment Partitioning (SBSP) model.

\begin{tabular}{lll}
\hline Symbol & Units & Description \\
\hline$t$ & $\mathrm{~T}$ & Time \\
$x_{\mathrm{S}}$ & $\mathrm{L}$ & Shoreline location \\
$x_{\mathrm{f}}$ & $\mathrm{L}$ & Foredune toe location \\
$x_{\mathrm{c}}$ & $\mathrm{L}$ & Foredune crest location \\
$x_{\mathrm{b}}$ & $\mathrm{L}$ & Backbarrier-marsh interface \\
$A$ & $\mathrm{~L}^{3} \mathrm{~L}^{-1}$ & Active subaerial cross section volume \\
$Z$ & $\mathrm{~L}$ & Sea level \\
\hline
\end{tabular}

Table 2. Input parameters for Subaerial Barrier Sediment Partitioning (SBSP) model.

\begin{tabular}{lll}
\hline Symbol & Units & Description \\
\hline$Q_{\mathrm{S}}$ & $\mathrm{L}^{3} \mathrm{~L}^{-1} \mathrm{~T}^{-1}$ & Shoreface flux \\
$Q_{\mathrm{D}}$ & $\mathrm{L}^{3} \mathrm{~L}^{-1} \mathrm{~T}^{-1}$ & Foredune flux \\
$L_{\mathrm{C}}$ & $\mathrm{L}$ & Critical ridge spacing \\
$L_{\mathrm{S}}$ & $\mathrm{L}$ & New foredune shoreline setback \\
$\Gamma_{1}, \Gamma_{2}$ & $\mathrm{LL}^{-1}$ & Front and back slope of subaerial surface \\
$D_{\mathrm{T}}$ & $\mathrm{L}^{-1}$ & Platform depth (depth to transgressive surface) \\
$\dot{z}$ & $\mathrm{~L} \mathrm{~T}^{-1}$ & Rate of sea-level rise (SLR) \\
\hline
\end{tabular}

could yield insights concerning the pace at which sedimentlimited barriers respond to changes in external forcing, including the rate of sea-level rise.

\section{Methods}

\subsection{Numerical framework}

This study utilizes an extended version of the "ridge and swale" cross-shore barrier framework of Ciarletta et al. (2019b), which we refer to as the Subaerial Barrier Sediment Partitioning (SBSP) model. The SBSP model assumes the same underlying controls on morphology as implemented in the earlier framework: the partitioning of sand to the subaerial barrier is governed by the rate of sand delivery to the beach through cross-shore and alongshore fluxes (e.g., shoreface fluxes), as well as the flux of sand from the beach to the foredune (e.g., foredune fluxes). However, instead of representing foredune volume with a discrete triangular profile, the SBSP model reduces the entire subaerial barrier into a landward-tapering profile (Fig. 3; state variables and input parameters; see Tables 1 and 2). In this way, the model captures not only the foredune but also the entire subaerial sandy backbarrier platform.

To simulate new foredune ridge development, the barrier surface can also be segmented into multiple triangular profiles that are capable of cross-shore amalgamation (a combination of swale-infilling and lateral growth) to form composite foredune structures (Fig. 4). As with the model of Ciarletta et al. (2019b), the formation of new foredune crests un- 


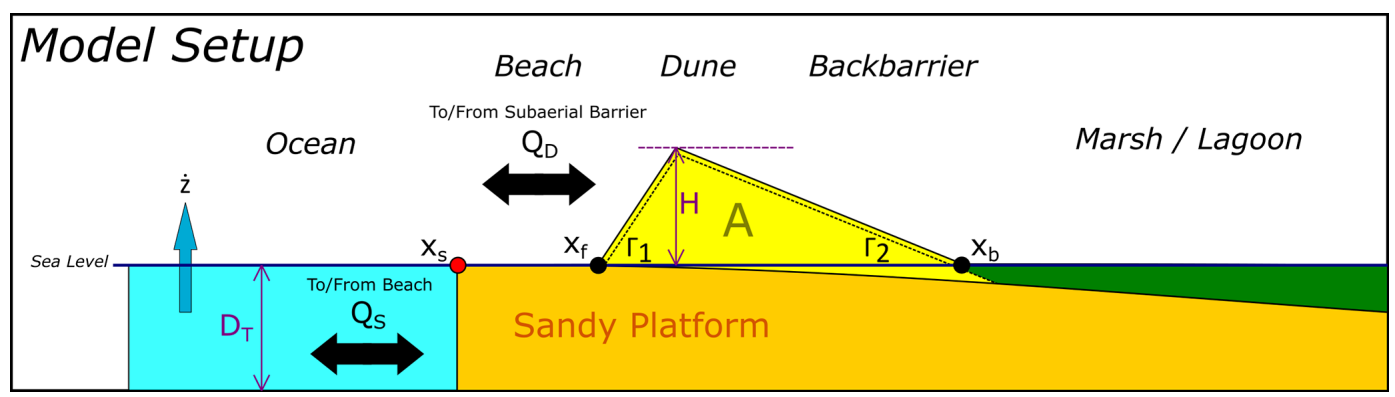

Figure 3. Subaerial Barrier Sediment Partitioning (SBSP) model setup, depicting moving boundaries and processes. Black arrows indicate the bi-directionality of shoreface-to-beach $\left(Q_{\mathrm{S}}\right)$ and beach-to-dune $\left(Q_{\mathrm{D}}\right)$ fluxes, where positive $Q_{\mathrm{S}}$ fluxes shift the shoreline (red dot, $\left.x_{\mathrm{S}}\right)$ seaward and positive $Q_{\mathrm{D}}$ fluxes increase the profile area $(A)$ of the active subaerial surface (yellow-shaded region above sea level), expanding the foredune toe $\left(x_{\mathrm{f}}\right)$ seaward and the backbarrier-marsh interface $\left(x_{\mathrm{b}}\right)$ landward (black dots). Increases in subaerial cross-sectional volume increase the foredune crest height as function of subaerial geometry, governed by the front slope of the subaerial surface $\left(\Gamma_{1}\right)$ and the back slope $\left(\Gamma_{2}\right)$. Coincident with flux contributions and losses, subaerial cross-sectional volume is lost to the subaqueous domain (yellow-shaded region below sea level, not included in $A$ ), becoming part of the barrier substructure due to sea-level rise $(\dot{z})$. The thickness of the barrier substructure is denoted by $D_{\mathrm{T}}$, the depth of the active shoreface over decadal timescales. The backbarrier slope of the sandy platform is shown for illustrative purposes and is not currently parameterized in the model.

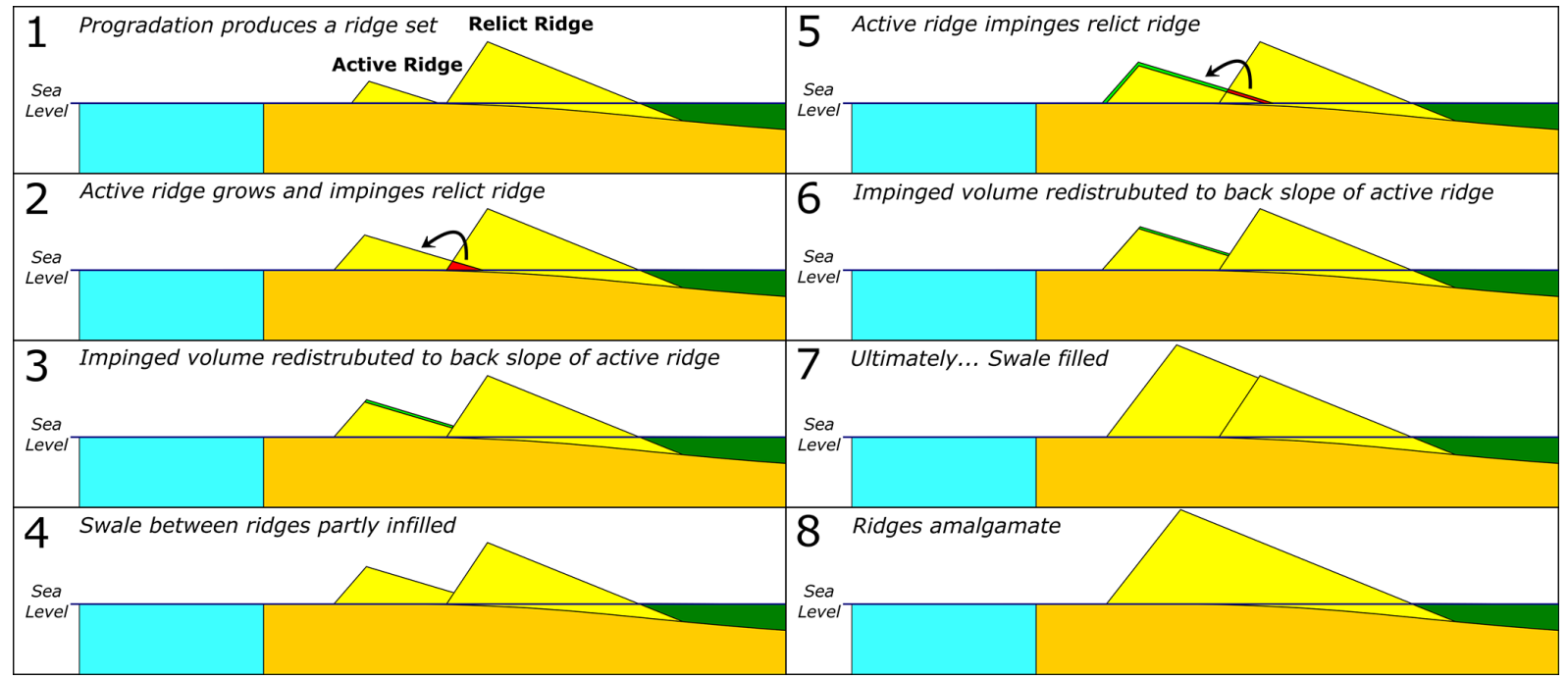

Figure 4. Conceptualization of swale-infilling and cross-shore foredune ridge amalgamation in the Subaerial Barrier Sediment Partitioning (SBSP) model. As an active ridge grows and impinges a landward or relict ridge, the inflating ridge volume is redistributed to fill the swale between ridges. When swale filling is complete, the active and relict ridges amalgamate into a single active ridge. Yellow represents barrier sand, blue represents ocean, and dark green represents marsh. Note that the backbarrier slope of the sandy platform is shown for illustrative purposes and is not currently parameterized in the model.

der prograding shoreline conditions occurs at a regular critical spacing $L_{\mathrm{C}}$. It is also assumed that incipient foredunes cannot form directly on the shoreline (see Durán Vinent and Moore, 2013), requiring a characteristic setback distance $L_{\mathrm{S}}$ (see Ciarletta et al., 2019b, for additional discussion).

From the idealized geometry shown in the model setup (Fig. 3), changes in the barrier system can be explained by just two state variables: the horizontal shoreline position $x_{\mathrm{s}}$ and the profile volume of the active subaerial barrier $A$. These boundaries change in response to modulation of shoreface fluxes $Q_{\mathrm{S}}$ and foredune fluxes $Q_{\mathrm{D}}$, respectively.
Specifically, the shoreline position is given by

$\frac{\mathrm{d} x_{\mathrm{s}}}{\mathrm{d} t}=\frac{Q_{\mathrm{s}}}{D_{\mathrm{T}}}-\frac{Q_{\mathrm{D}}}{D_{\mathrm{T}}}-\frac{\left(x_{\mathrm{s}}-x_{\mathrm{f}}\right) \cdot \dot{z}}{D_{\mathrm{T}}}$,

where $Q_{\mathrm{S}} / D_{\mathrm{T}}$ and $Q_{\mathrm{D}} / D_{\mathrm{T}}$ are the sediment delivery to the beach and to the foredune, respectively, divided by the timedependent depth of accommodation at the shoreface $D_{\mathrm{T}}$. The final term represents the loss of beach volume to sea-leveldriven accommodation creation ( $\dot{z}$ is rate of sea level rise, and $x_{\mathrm{s}}-x_{\mathrm{f}}$ is cross-shore width of the beach). 
The cross-sectional volume $A$ of the subaerial barrier is a function of foredune fluxes $Q_{\mathrm{D}}$ and the loss of subaerial volume to the subaqueous domain as sea level $Z$ rises. Specifically, the volume of the subaerial barrier is given by

$\frac{\mathrm{d} A}{\mathrm{~d} t}=Q_{\mathrm{s}}-\left(x_{\mathrm{b}}-x_{\mathrm{f}}\right) \cdot \dot{z}$,

where $x_{\mathrm{b}}-x_{\mathrm{f}}$ is the width of the barrier subaerial profile, excluding the beach.

From $A$, and given the front and back slopes of the subaerial barrier $\left(\Gamma_{1}, \Gamma_{2}\right)$, it is possible to calculate the height of the foredune crest as $H=\left[2 \cdot A /\left(1 / \Gamma_{1}+1 / \Gamma_{2}\right)\right]^{1 / 2}$. As $H$ updates through time, the values of $x_{\mathrm{b}}$ and $x_{\mathrm{f}}$ can similarly be computed algebraically by

$x_{\mathrm{f}}=x_{\mathrm{c}}-\frac{H}{\Gamma_{1}}$,

$x_{\mathrm{b}}=x_{\mathrm{c}}-\frac{H}{\Gamma_{2}}$,

where $x_{\mathrm{c}}$ is the active foredune crest location. The crest location is supplied as an initial input but updates as new foredune crests are created or old crests are reactivated through exposure to the active beach coincident with shoreline transgression. During foredune creation, a new $x_{\mathrm{c}}$ is established once $\left(x_{\mathrm{S}}-x_{\mathrm{f}}\right)+H / \Gamma_{1} \geq L_{\mathrm{C}}+L_{\mathrm{S}}$ or when the combined width of the beach and seaward flank of the subaerial barrier profile is greater than the critical spacing plus the setback distance.

Unlike in Ciarletta et al. (2019b), all the equations can now run "backwards", simulating erosion and transgression by accepting negative flux values until all volume has been exhausted from the barrier profile. To implement subaerial volume loss through shoreline transgression, a simple geometric rule is applied. Erosion that undercuts the subaerial profile scarps the profile at a slope of $\Gamma_{1}$ (Fig. 5). Volume scarped from the subaerial profile is then conserved to the beach, having the effect of counteracting negative shoreface fluxes. No volume is lost directly from the subaerial domain to outside the system - all volume is conserved unless removed by negative shoreface sediment fluxes.

We solve Eqs. (1) to (4) using the Euler method over decadal to centennial scales and at an annual time step. Starting geometry is provided by the model input parameters outlined in Table 2 and described for individual investigations in the next section. The beach in our simulations is flat and maintains elevation with sea level $Z$. Where the width of the barrier is calculated in our results, we compute this term as $x_{\mathrm{s}}-x_{\mathrm{b}}$. This is different from the width of the subaerial profile coincident with $A$, which is calculated as $x_{\mathrm{f}}-x_{\mathrm{b}}$.

The initial input parameters used to describe the modeled barrier used in our investigations are shown in Table 3. In terms of the barrier superstructure, critical ridge spacing $L_{\mathrm{C}}$ and front slope $\Gamma_{1}$ are informed by parameters observed at Fishing Point (southern spit end of Assateague Island, Maryland and Virginia, USA) and Parramore Island (Ciarletta et al., 2019b), with the main difference being a slightly

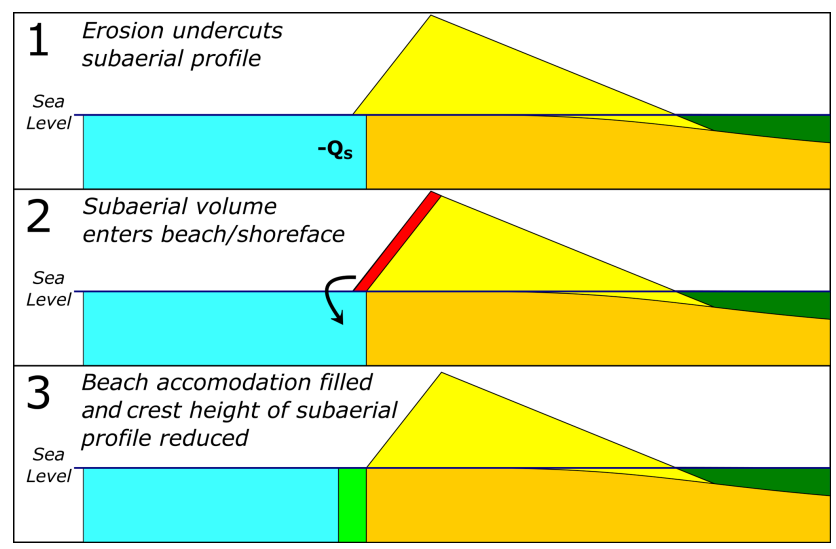

Figure 5. Conceptualization of erosion and redistribution of volume in subaerial profile. As the shoreline erodes landward, the subaerial profile is undercut and scarped according to the subaerial front slope $\Gamma_{1}$. Scarped volume is transferred to the beach or shoreface and fills accommodation to extend the shoreline seaward as a function of volume divided by depth. Some of this sand volume may then be lost from the system through continued beach erosion. Yellow represents barrier sand, blue represents ocean, and dark green represents ,marsh. $Q_{\mathrm{S}}$ stands for shoreface flux.

Table 3. Inputs investigated for Subaerial Barrier Sediment Partitioning (SBSP) model.

\begin{tabular}{lll}
\hline Symbol & $Q_{\mathrm{s}}$ vs. SLR & $Q_{\mathrm{s}}$ vs. $Q_{\mathrm{D}}$ \\
\hline$Q_{\mathrm{S}}$ & -20 to $^{3} \mathrm{~m}^{3} \mathrm{~m}^{-1} \mathrm{yr}^{-1}$ & -10 to $50 \mathrm{~m}^{3} \mathrm{~m}^{-1} \mathrm{yr}^{-1}$ \\
$Q_{\mathrm{D}}$ & $30 \mathrm{~m}^{3} \mathrm{~m}^{-1} \mathrm{yr}^{-1}$ & 0 to $75 \mathrm{~m}^{3} \mathrm{~m}^{-1} \mathrm{yr}^{-1}$ \\
$L_{\mathrm{C}}$ & $130 \mathrm{~m}$ & $130 \mathrm{~m}$ \\
$L_{\mathrm{S}}$ & $30 \mathrm{~m}$ & $30 \mathrm{~m}$ \\
$\Gamma_{1}, \Gamma_{2}$ & $0.06,0.006$ & $0.06,0.006$ \\
$D_{\mathrm{T}}$ & 2.5 to $5 \mathrm{~m}$ & 2.5 to $5 \mathrm{~m}$ \\
$\dot{z}$ & 0 to $20 \mathrm{~mm} \mathrm{yr}^{-1}$ & $1 \mathrm{~mm} \mathrm{yr}$ \\
$H_{\text {initial }}$ & $2 \mathrm{~m}$ & $2 \mathrm{~m}$ \\
$t_{\text {max }}$ & 43 to $500 \mathrm{yr}$ & $500 \mathrm{yr}$ \\
\hline
\end{tabular}

larger spacing to acknowledge some of the wider swales between relict foredunes visible at other US East Coast barriers, including Fire Island, New York. In terms of the nucleation location of a new foredune $\left(L_{\mathrm{s}}\right)$, Durán Vinent and Moore (2013) note that at least initially the maximum height achievable by a foredune scales as a function of setback. Assuming a stationary barrier similar to the central regions of Fire Island and Assateague Island, a 3 to $5 \mathrm{~m}$ tall aeolian dune could develop for a reasonable range of wind-induced shear values when $L_{\mathrm{s}}$ is approximately $30 \mathrm{~m}$. Subsequently, we also start the model with an initial beach width $\left(x_{\mathrm{s}}-x_{\mathrm{f}}\right)$ equal to $L_{\mathrm{S}}$. For the last parameter affecting the subaerial geometry, $\Gamma_{2}$, our modeled barrier has a backbarrier width $\left(x_{\mathrm{f}}-x_{\mathrm{b}}\right)$ that scales an order of magnitude larger than the distance between the foredune crest $x_{\mathrm{c}}$ and the effective base of the dune, $x_{\mathrm{f}}$. 
In the substructure, our model barrier uses initial $D_{\mathrm{T}}$ values (sandy-substructure accommodation) in the range of 2.5 to $5 \mathrm{~m}$. The smaller value was selected based on the sandy platform depths seen in western central Florida barriers (Locker et al., 2001, 2002a-d). The larger value is the same as that used in Ciarletta et al. (2019b), and is based on stratigraphic data from Parramore Island and Fishing Point (Halsey, 1978; Raff et al., 2018; Hein et al., 2019).

Our range of tested values for $Q_{\mathrm{S}}$ and $Q_{\mathrm{D}}$ is similarly inspired by real-world field sites. Himmelstoss et al. (2017) notes that long-term beach accretion along US southeastern and Gulf coast barrier islands generally occurs on the order of 8.5 to $33.5 \mathrm{~m} \mathrm{yr}^{-1}$. If assuming a reasonable sandy substructure thickness $(\sim 5 \mathrm{~m})$, this would be equivalent to shoreface fluxes on the order of 43 to $168 \mathrm{~m}^{3} \mathrm{~m}^{-1} \mathrm{yr}^{-1}$. Globally, beach-ridge plain systems tend to have slower rates of extension, on the order of 0.4 to $1.4 \mathrm{~m} \mathrm{yr}^{-1}$, scaling to 2 to $7 \mathrm{~m}^{3} \mathrm{~m}^{-1} \mathrm{yr}^{-1}$ (Bristow and Pucillo, 2006: Brooke et al., 2008; Hein et al., 2016). In the subaerial domain, a global compilation of field sites suggests foredune fluxes may occur on the order of 0 to $40 \mathrm{~m}^{3} \mathrm{~m}^{-1} \mathrm{yr}^{-1}$ (Ciarletta et al., 2019b, Supplement); although we test somewhat higher values to account for cases where $Q_{\mathrm{D}}$ may greatly exceed $Q_{\mathrm{S}}$ by more than an order of magnitude.

\subsection{Exploration of model behaviors}

We explore the morphology and behavior of simulated barriers within the SBSP framework through two principal lines of investigation: (1) quantifying thresholds of behavioral and morphological change based on combinations of shoreface sediment fluxes $Q_{\mathrm{S}}$ and variable rates of SLR $(\dot{z})$ and (2) exploring the full spectrum of barrier transgressive behavior, which is hypothesized to be richer than as conceptualized by Psuty (2008) (see Fig. 1) based on a number of field sites that show evidence of dune dominance, or net accumulation of sediment in the foredunes, despite shoreline erosion. The latter investigation tests different combinations of $Q_{\mathrm{S}}$ and $Q_{\mathrm{D}}$, allowing $Q_{\mathrm{D}}$ to exceed $Q_{\mathrm{S}}$ by over an order of magnitude - the inverse of what was previously examined in Ciarletta et al. (2019b), which focused purely on scenarios of neutral to positive beach sediment budget. Within both lines of investigation, we also evaluate different sandysubstructure accommodation depths $\left(D_{\mathrm{T}}\right)$ to compare the sensitivity of sediment-rich and sediment-starved barriers to the same range of flux magnitudes.

In each investigation we explore impacts on barrier morphology by examining the state of four variables: the width of the barrier $W$ (where $W=x_{\mathrm{s}}-x_{\mathrm{b}}$ ), the number of foredune crests $N$, the height of the active foredune crest $H$, and the location of the barrier-marsh interface $x_{\mathrm{b}}$. A result of $N>1$ allows us to quickly diagnose that progradation has occurred and in combination with $W$ and $x_{\mathrm{b}}$ can help illuminate the impact of backbarrier drowning. Where $N=1$, we can identify stable and transgressive dunes, determine if

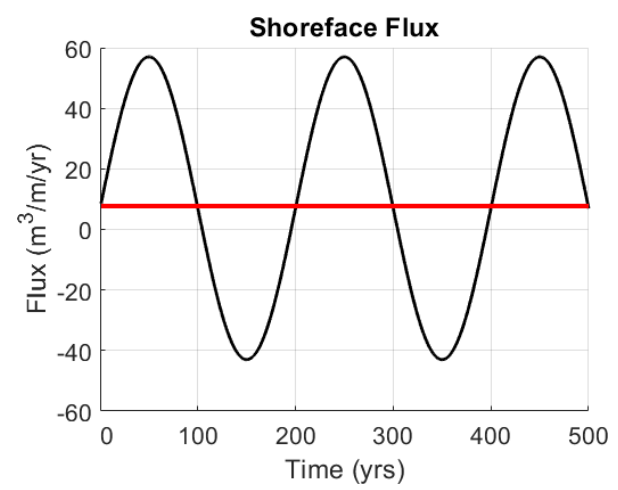

Figure 6. Shoreface flux $Q_{\mathrm{S}}$ supplied as a function of sine wave centered on $+7 \mathrm{~m}^{3} \mathrm{~m}^{-1} \mathrm{yr}^{-1}$ (net positive).

they are growing or losing volume by examining $H$, and determine if inland migration has occurred by comparing $x_{\mathrm{b}}$ and $W$. Note that $x_{\mathrm{s}}$ is also known as long as $W$ and $x_{\mathrm{b}}$ are tracked. To capture the loss of foredune volume through time under transgressive regimes, we also initialize the model with a modest $2 \mathrm{~m}$ high dune.

\section{Results}

\subsection{Visual quasi-stratigraphic output}

The model explorations outlined in the previous section are sensitivity analyses that rely on regime plots of $N, W, H$, and $x_{\mathrm{b}}$ to interpret morphology and behavior. To demonstrate model behaviors in a two-dimensional cross-shore sense, we first describe an example barrier evolution with graphical outputs that depict morphology as shown in Figs. 3-5. Here, we use the model inputs for the $Q_{\mathrm{S}}$ vs. SLR investigation (Table 3 ) but hold $\dot{z}$ constant at $6 \mathrm{~mm} \mathrm{yr}^{-1}$ and set the initial dune height to $0 \mathrm{~m}$, while modulating $Q_{\mathrm{S}}$ with a sine function to simulate an oscillatory sediment flux. We center our sine function on a flux of $+7 \mathrm{~m}^{3} \mathrm{~m}^{-1} \mathrm{yr}^{-1}$, with an amplitude of $50 \mathrm{~m}^{3} \mathrm{~m}^{-1} \mathrm{yr}^{-1}$, such that the maximum flux is $57 \mathrm{~m}^{3} \mathrm{~m}^{-1} \mathrm{yr}^{-1}$ and the minimum flux is $-43 \mathrm{~m}^{3} \mathrm{~m}^{-1} \mathrm{yr}^{-1}$. The period of the oscillations is set to 200 years (Fig. 6), comparable to the magnitude of timescales over which significant changes in sediment flux are inferred at some US East Coast barriers (Leatherman, 1985; Deaton et al., 2017; Ciarletta et al., 2019b).

A total of 10 years after initialization (Fig. 7a), our duneless example barrier develops a significant subaerial superstructure with a height of $1.4 \mathrm{~m}$. Height growth is rapid in the first few years due to a high ratio of accumulation surface to cross-sectional volume; as time progresses and the superstructure of the barrier enlarges, the rate of vertical growth slows. This mirrors the relationship observed by DavidsonArnott et al. (2018) that, assuming a relatively constant sand source and flux, dune growth slows (but never reaches zero) as the dimensions of the dune increase with time. 
Barrier Evolution with Time: Oscillating Sediment Delivery Regime
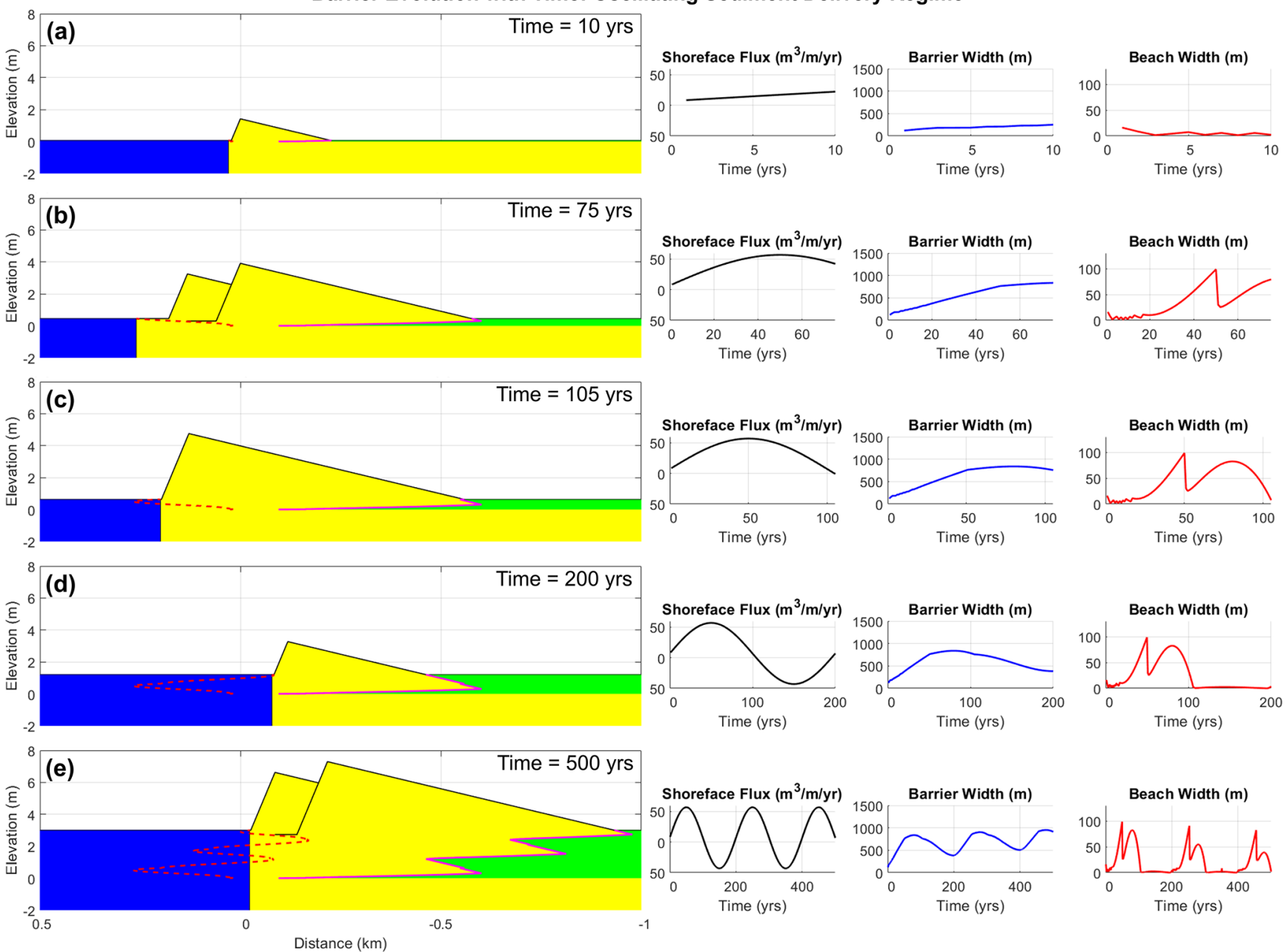

Figure 7. Example simulation of a barrier subjected to a periodically oscillating shoreface sediment flux. Graphical output displays barrier at progressive time steps of 10,75, 105, 200, and 500 years post-initialization, undergoing state shifts between progradation and transgression. In the profile morphologies (left), yellow represents barrier sand, blue represents ocean, green represents marsh. The solid magenta line tracks the position of barrier-marsh interface, while the dashed red line tracks the shoreline position.

At 75 years into the model run, positive sediment fluxes result in progradation of the barrier and subsequent development of a new foredune ridge seaward of the original ridge. The sandy superstructure also built landward into the marsh prior to creation of the new foredune, burying old marsh surfaces previously adjacent to the backbarrier. Now that the original foredune has become relict, the flow of sediment to the backbarrier is cut off, and the marsh is beginning to passively drown the backbarrier surface as sea level continues to rise (Fig. 7b).

After 105 years of simulation (Fig. 7c), fluxes at the shoreface reach zero, but for the latter 30 of those years decreasing fluxes have been unable to compensate for increasing accommodation driven by sea-level rise at the front of the barrier, resulting in landward migration of the shoreline. The seaward foredune continued to grow over the same timeframe, encroaching and filling the swale and separating it from the landward and relict foredune. In the current time step (105 years), the seaward foredune has filled all remaining swale accommodation and merged with the landward foredune, completing the process of cross-shore amalgamation. Now, as sediment fluxes become negative (triggering accelerated erosion and landward shoreline migration), the subaerial superstructure will become scarped.

At 200 years into the model run, now with exposure to 100 years of net negative shoreface fluxes, the barrier has undergone erosion on its seaward flank and passive drowning (marsh encroachment) on its landward flank (Fig. 7d). Its total width, which peaked at $837 \mathrm{~m} 120$ years earlier, is now only $384 \mathrm{~m}$. Evidence of earlier progradation at the front of the barrier has been eroded away, but the interfingering of sand and marsh facies in the backbarrier substructure indicates that the barrier dimensions were once larger. As shoreface fluxes become positive, the barrier will rede- 

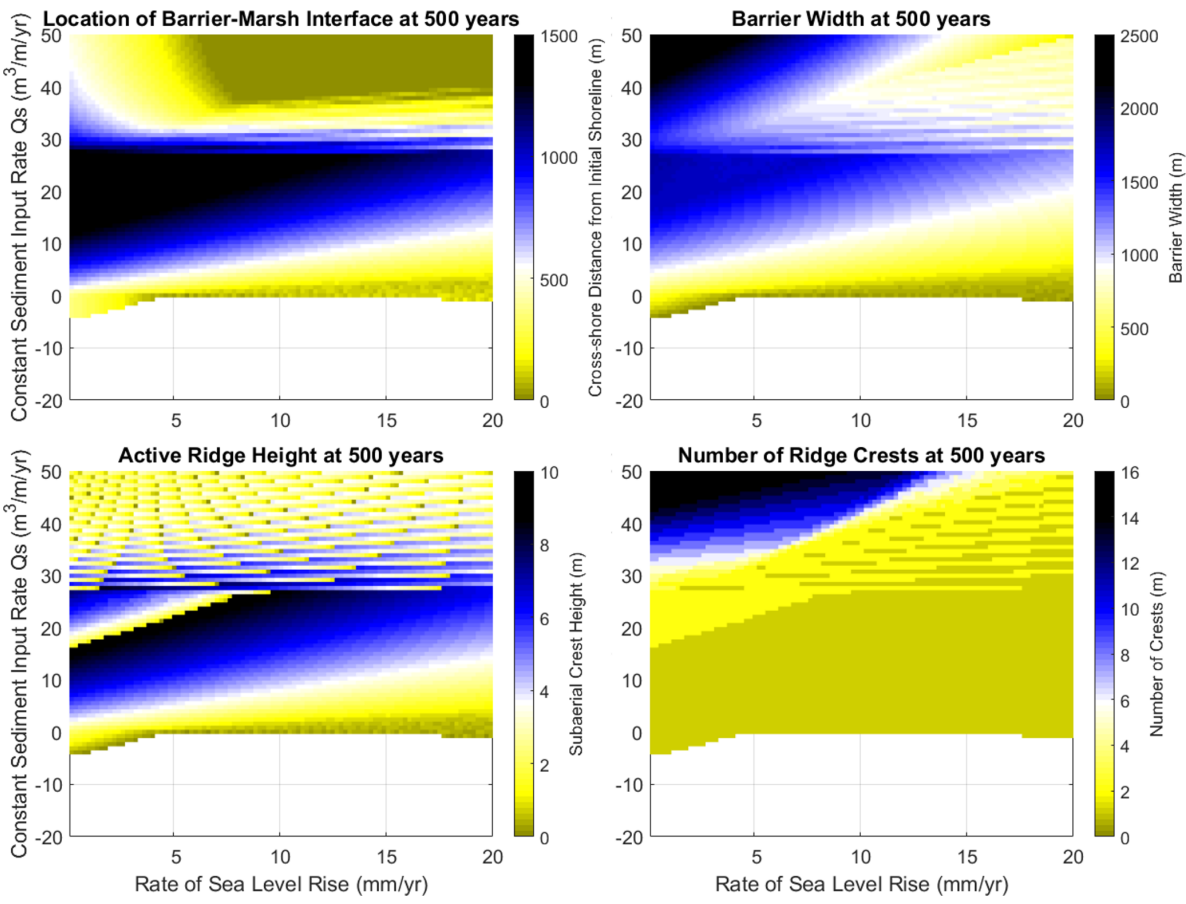

Figure 8. Plots of barrier-marsh interface location $x_{\mathrm{b}}$, barrier width $W$, active foredune crest height $H$, and number of foredune ridges $N$ for a 500 -year simulation of a modeled barrier with input parameters described by Table 3 and $D_{\mathrm{T}}=5 \mathrm{~m}$. Regions with no data (generally negative sediment input) correspond with complete dune loss and potential barrier disintegration. $D_{\mathrm{T}}$ is the thickness of the barrier substructure or the depth of the active shoreface over decadal timescales. $Q_{\mathrm{S}}$ represents shoreface flux. Note that the active ridge height and number of ridge crests do not change synchronously at the end of each 500-year simulation due to the presence of amalgamation. Discontinuities in the plot of active ridge height generally align with the plot of ridge crests produced, but where they differ it is because amalgamation can reduce the number of ridges while maintaining the height of the active ridge.

velop, although this will be from a position $120 \mathrm{~m}$ landward of where it was initialized. Despite having a slightly net positive sediment flux, transgression driven by sea-level rise has increased vertical accommodation, forcing net retreat overall.

At the end of the model run, 500 years later, the barrier has undergone three cycles of progradation and two cycles of transgression and drowning (Fig. 7e). Evidence of prior constructive and destructive phases of morphologic evolution are buried beneath the contemporary barrier in the form of sand-marsh interfingers. However, on the surface, the modern barrier might only appear to be a long-term transgressive system that has recently undergone progradation. If the model run was extended for another 500 years, some of the stratigraphy preserved under the barrier would be eroded by the shoreface, destroying the record of the earliest phases of progradation and transgression.

\subsection{Shoreface flux vs. sea-level rise}

Our investigation of shoreface flux vs. SLR reveals a complex pattern of barrier morphological response as depicted through tracking of $x_{\mathrm{b}}, W, H$, and $N$ (Fig. 8). At 500 years of barrier evolution, most outcomes with negative sediment fluxes result in "destructive" transgression, characterized ultimately by complete loss of the barrier superstructure. We describe this simply as "dune loss", although it could also be the beginning of barrier island disintegration if the sandy substructure undergoes drowning or is depleted of sediment by continued erosion. Such outcomes would be delayed if the starting subaerial volume were larger (relative to our foredune modeled with an initial crest height of $2 \mathrm{~m}$ ). Where sediment fluxes are positive, the vast majority of $Q_{\mathrm{S}}$ fluxes between 0 and $32 \mathrm{~m}^{3} \mathrm{~m}^{-1} \mathrm{yr}^{-1}$ bracket a stable (subaerial constructional) transgressive form of barrier development, as well as predominantly aggradational to mildly progradational forms ("pre-amalgamation") where SLR is less than $12 \mathrm{~mm} \mathrm{yr}^{-1}$ and $Q_{\mathrm{S}}$ is greater than $17 \mathrm{~m}^{3} \mathrm{~m}^{-1} \mathrm{yr}^{-1}$. The entire region between 0 and $32 \mathrm{~m}^{3} \mathrm{~m}^{-1} \mathrm{yr}^{-1}$ is strongly modulated by sea-level rise, with increasing SLR thinning and reducing the height of the barrier, especially for low rates of positive shoreface flux (e.g., $5 \mathrm{~m}^{3} \mathrm{~m}^{-1} \mathrm{yr}^{-1}$ compared to $25 \mathrm{~m}^{3} \mathrm{~m}^{-1} \mathrm{yr}^{-1}$ ). These behaviors largely correspond with the barrier geometry demonstrated in Fig. 7d.

A significant break in behavior and morphology is developed at $Q_{\mathrm{S}}=32 \mathrm{~m}^{3} \mathrm{~m}^{-1} \mathrm{yr}^{-1}$, where increasing shoreface flux results in the ability of the beach sand budget to adequately compensate for $Q_{\mathrm{D}}$ fluxes and loss of volume to 
(a)

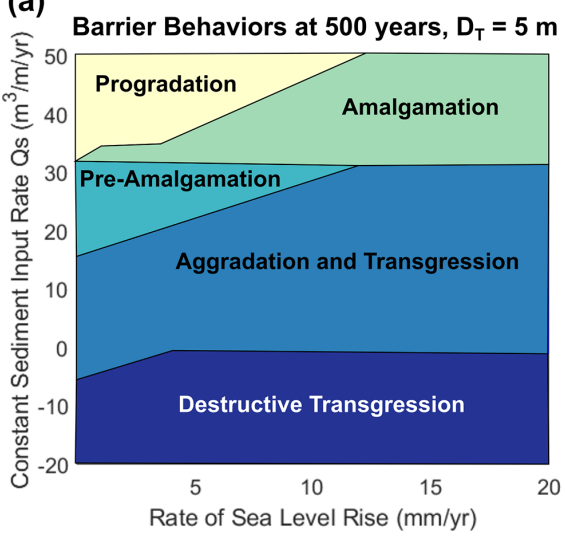

(b)

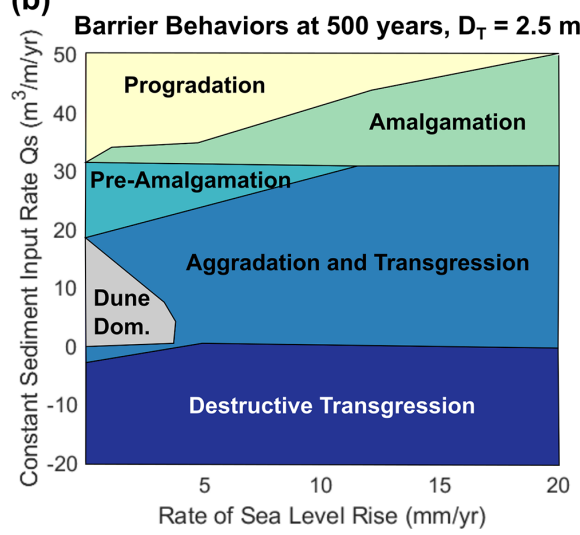

Figure 9. Behavior of the modeled barrier in response to combinations of $Q_{\mathrm{S}}$ and SLR over 500 years for (a) $D_{\mathrm{T}}=5 \mathrm{~m}$ and (b) $D_{\mathrm{T}}=2.5 \mathrm{~m}$. A region of $D_{\mathrm{T}}=2.5 \mathrm{~m}$ where SLR is less than $5 \mathrm{~mm} \mathrm{yr}^{-1}$ and $Q_{\mathrm{S}}$ is between 0 and $20 \mathrm{~m}^{3} \mathrm{~m}^{-1} \mathrm{yr}^{-1}$ is subject to "dune dominance", where the barrier volume is preferentially stored in the subaerial domain. $D_{\mathrm{T}}$ is the thickness of the barrier substructure or the depth of the active shoreface over decadal timescales. $Q_{\mathrm{S}}$ represents shoreface flux.

dune aggradation. In this region, sea-level rise still exerts an impact on barrier morphology, splitting outcomes into two morphological end-members. Specifically, at high rates of SLR, mostly exceeding $5 \mathrm{~mm} \mathrm{yr}^{-1}$, multi-ridge propagation is impossible, as increasing accommodation in the shoreface prevents the shoreline from rapidly prograding. With slower progradation, cross-shore ridge amalgamation (similar to Fig. 7c; see also Fig. 4) dominates the response of the barrier, with the number of ridge crests $N$ alternating between 1 and 2 through time as each new seaward ridge is allowed time to grow before merging with the previous, relict ridge. At slower rates of SLR, accommodation at the shoreface is filled much faster than it is lost to vertical accommodation and true progradation prevails, with the shoreline able to extend rapidly seaward - this triggers the production of a series of relict foredune ridges in the cross-shore $(N \geq 2)$.

A simplified "map" of all the aforementioned responses is shown in Fig. 9, which also shows the change in morphological outcomes if initial $D_{\mathrm{T}}$ is adjusted from 5 to $2.5 \mathrm{~m}$. At a timescale of 500 years, differences in combinations of $Q_{\mathrm{S}}$ and SLR that result in destructive transgression are negligible, as loss of the barrier profile largely occurs within the first 200 years for both scenarios. However, at centennial scales the impact of decreased sandy-substructure accommodation is noticeable in the division between progradational and amalgamative behaviors. At $D_{\mathrm{T}}=2.5 \mathrm{~m}$ and for the range of input fluxes tested here, progradation can occur at up to $20 \mathrm{~mm} \mathrm{yr}^{-1}$ of SLR, whereas at $D_{\mathrm{T}}=5 \mathrm{~m}$ progradation only occurs up to $12 \mathrm{~mm} \mathrm{yr}^{-1}$ in the highest input flux case. Additionally, for the shallower substructure depth, a new behavioral regime becomes apparent when SLR is less than $5 \mathrm{~mm} \mathrm{yr}^{-1}$ and $Q_{\mathrm{S}}$ is between 0 and $20 \mathrm{~m}^{3} \mathrm{~m}^{-1} \mathrm{yr}^{-1}$. This regime, "dune dominance" is characterized by runaway subaerial growth as the reduced accommodation at the beach allows for gradual shoreline regression even under relatively low shoreface flux conditions, similar to the example of the Florida barrier islands (see Sect. 2). This permits subaerial accumulation (reflected in increasing $H$ and $x_{\mathrm{b}}$; see Fig. 10), which halts only when the seaward foredune toe $\left(x_{\mathrm{f}}\right)$ meets the shoreline. When this occurs, subsequent scarping temporarily recycles sand back into the beach before it is fed back to the subaerial superstructure in the next time step along with any new shoreface fluxes. Investigation in the next section shows that such a response only occurs when $Q_{\mathrm{D}}>Q_{\mathrm{S}}$, and it is not apparent in the response regime for $D_{\mathrm{T}}=5 \mathrm{~m}$ because the enhanced platform accommodation consumes volume for vertical aggradation faster than it can be partitioned to the subaerial portion of the system.

\subsection{Shoreface flux vs. foredune flux}

For our investigation of shoreface flux vs. foredune flux $\left(Q_{\mathrm{S}}\right.$ vs. $Q_{\mathrm{D}}$ ), which focuses on previously unexplored transgressive retreat behaviors (see Ciarletta et al., 2019b), we use plots of $x_{\mathrm{b}}$ and $H$ to differentiate behavioral modes (Fig. 11), supplemented by quasi-stratigraphic cross-shore model outputs (Fig. 12). For both $D_{\mathrm{T}}=2.5$ and $5 \mathrm{~m}$, the plots demonstrate a complex behavioral regime in the aggradational to transgressive region $\left(Q_{\mathrm{D}} \geq Q_{\mathrm{S}}\right)$, largely controlled by "dune dominance", in which the subaerial portion of the system consumes and stores the majority of the barrier-system volume. In the simplest terms, as the magnitude of $Q_{\mathrm{D}}$ increases beyond the magnitude of $Q_{\mathrm{S}}$, there is a gradient whereby the subaerial barrier initially becomes dune-dominated aggradational (accumulating sediment in the foredune but with a relatively stationary shoreline) and gradually transitions towards dune-dominated transgression (still accumulating sediment in the foredune but undergoing landward migration simultaneously). Transitions from dune-dominated aggrada- 

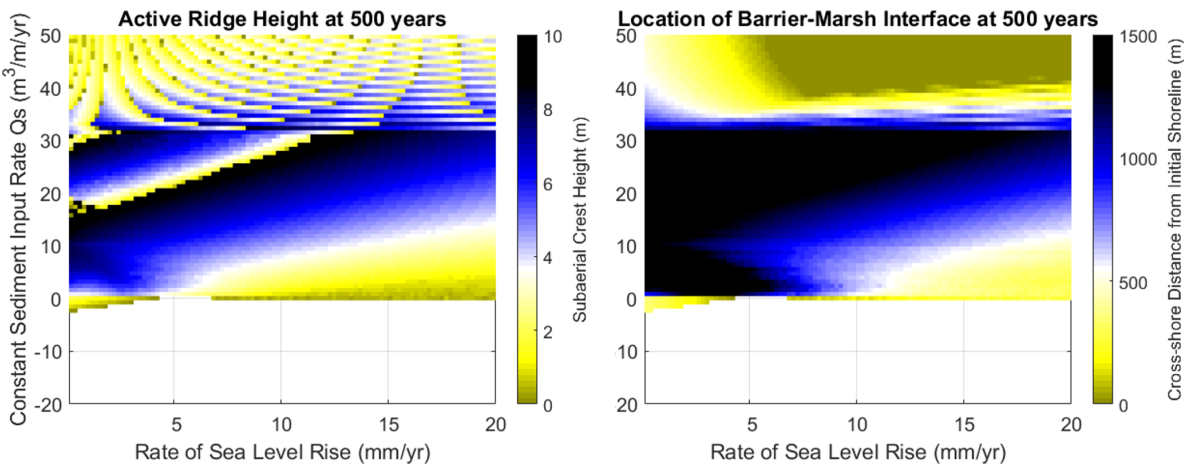

Figure 10. Plots of active foredune crest height $H$ and barrier-marsh interface location $x_{\mathrm{b}}$ for a 500-year simulation of a modeled barrier with input parameters described by Table 3 where $D_{\mathrm{T}}=2.5 \mathrm{~m}$. Regions with no data (generally negative sediment input) correspond with complete destruction of the barrier's subaerial superstructure. $D_{\mathrm{T}}$ is the thickness of the barrier substructure or the depth of the active shoreface over decadal timescales. $Q_{\mathrm{S}}$ represents shoreface flux, and $x_{\mathrm{b}}$ represents the cross-shore location of the backbarrier-marsh interface.

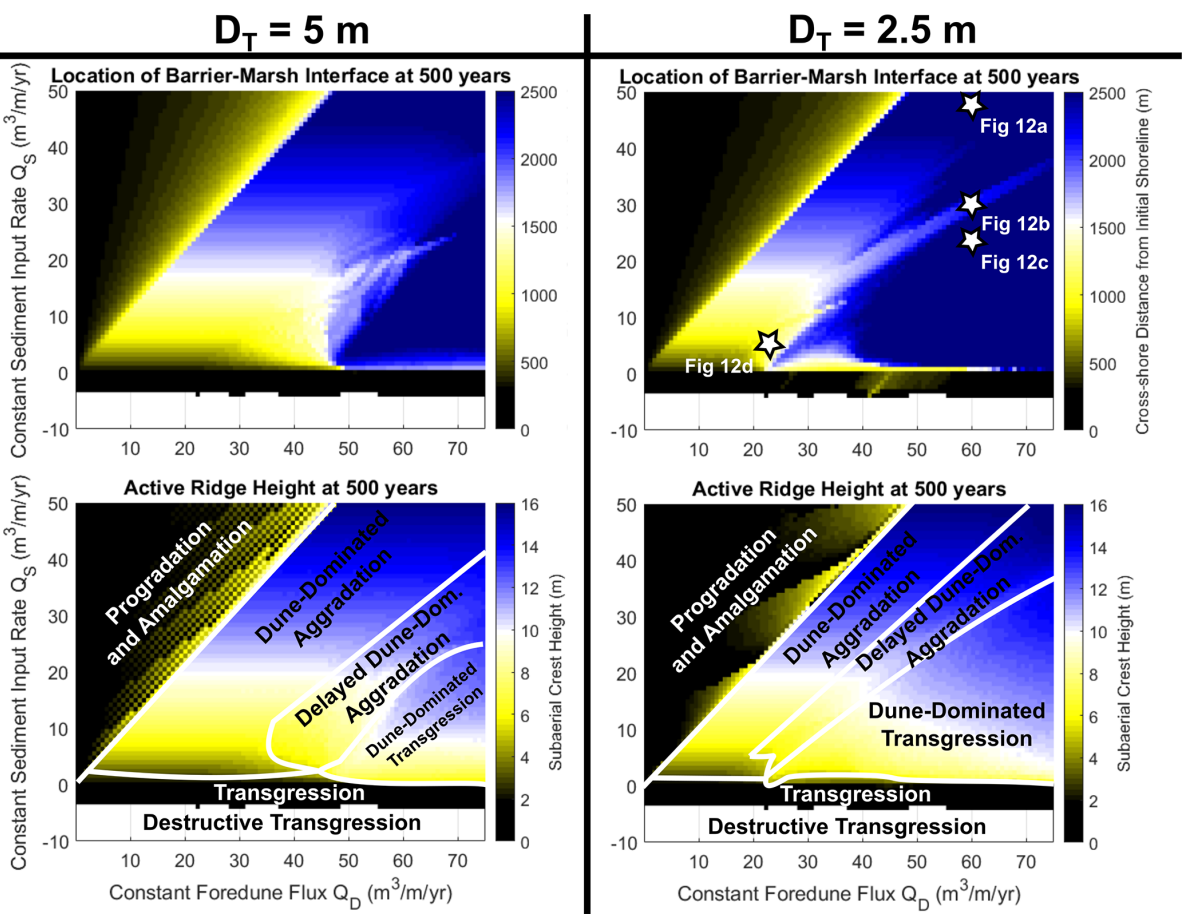

Figure 11. Plots of barrier-marsh interface location $x_{\mathrm{b}}$ and active foredune crest height $H$ for a 500-year simulation of a modeled barrier with input parameters described by Table 3 where $D_{\mathrm{T}}=5$ and $2.5 \mathrm{~m}$. Regions with no data (destructive transgression) correspond with complete dune loss and potential barrier disintegration. $D_{\mathrm{T}}$ is the thickness of the barrier substructure, or the depth of the active shoreface over decadal timescales. $Q_{\mathrm{S}}$ represents shoreface flux.

tion to transgression occur over a smaller range of $Q_{\mathrm{D}}$ values at $D_{\mathrm{T}}=2.5 \mathrm{~m}$ (less shoreface accommodation) than for $D_{\mathrm{T}}=5 \mathrm{~m}$ (more shoreface accommodation), as the volume of sediment needed to grow or erode the beach is smaller for shallower $D_{\mathrm{T}}$. Overall, this makes the barrier more sensitive to changes in fluxes and promotes dune-dominated transgression (compare the extent of transgression regimes on the $Q_{\mathrm{D}}$ axis for $D_{\mathrm{T}}=5$ and $D_{\mathrm{T}}=2.5 \mathrm{~m}$ ) as state shifts towards the transgressive end-member are imparted by relatively small differences in $Q_{\mathrm{D}}$.
We describe the gradient in greater detail by examining scenarios starred in the plot of $x_{\mathrm{b}}$ for $D_{\mathrm{T}}=2.5 \mathrm{~m}$ (Fig. 11). To begin, we examine a relatively high shoreface flux $\left(Q_{\mathrm{S}}=\right.$ $48 \mathrm{~m}^{3} \mathrm{~m}^{-1} \mathrm{yr}^{-1}$ ) counterbalanced by a similar magnitude (but slightly larger) foredune flux $\left(Q_{\mathrm{D}}=60 \mathrm{~m}^{3} \mathrm{~m}^{-1} \mathrm{yr}^{-1}\right)$ (Fig. 12a). Over the course of 500 years, the subaerial barrier becomes increasingly inflated, its growth paused only by episodes of occasional scarping as the seaward flank grows into the shoreline (marked by rapid fluctuations in beach width). When this occurs, scarping results in a transient re- 

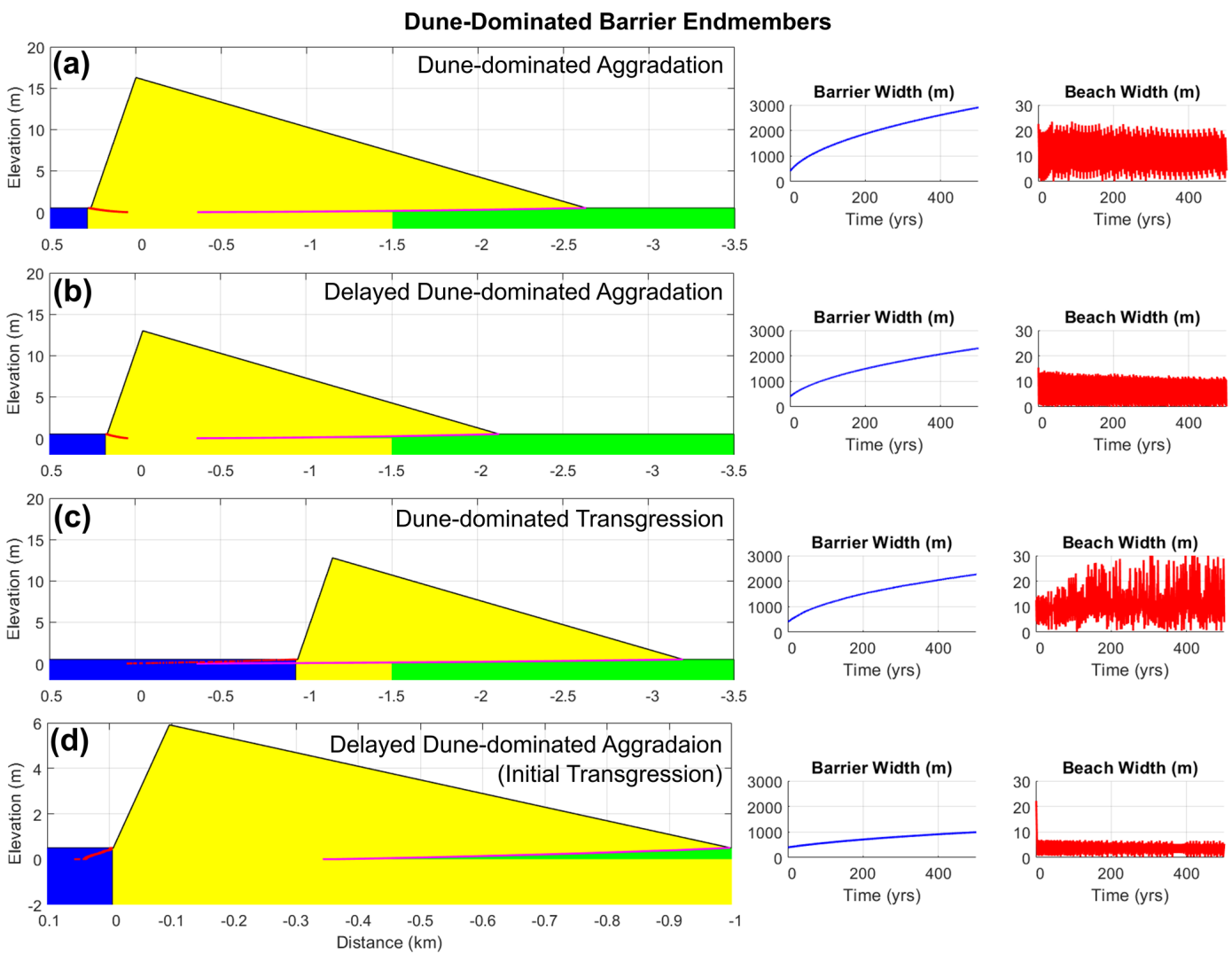

Figure 12. Simulated barriers at 500 years post-initialization. (a) Dune-dominated aggradation concomitant with $48 \mathrm{~m}^{3} \mathrm{~m}^{-1} \mathrm{yr}^{-1} \mathrm{of}^{-}$

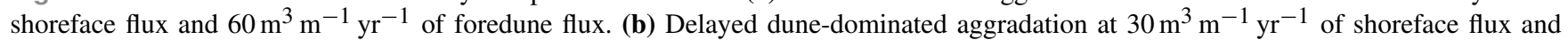
$60 \mathrm{~m}^{3} \mathrm{~m}^{-1} \mathrm{yr}^{-1}$ of foredune flux. (c) Dune-dominated transgression at $23 \mathrm{~m}^{3} \mathrm{~m}^{-1} \mathrm{yr}^{-1}$ of shoreface flux and $60 \mathrm{~m}^{3} \mathrm{~m}^{-1} \mathrm{yr}^{-1} \mathrm{of} \mathrm{foredune}^{-1}$ flux. (d) Delayed dune-dominated aggradation (pronounced initial transgression) at $5 \mathrm{~m}^{3} \mathrm{~m}^{-1} \mathrm{yr}^{-1}$ of shoreface flux and $22 \mathrm{~m}^{3} \mathrm{~m}^{-1} \mathrm{yr}^{-1}$ of foredune flux. Yellow represents barrier sand, blue represents ocean, green represents marsh. The solid magenta line tracks the position of the barrier-marsh interface, while the dashed red line tracks the shoreline position through time.

turn of sediment to the beach or shoreface, with volume ultimately recycled back to the subaerial barrier (with some loss to minor seaward progradation and vertical aggradation).

When maintaining the foredune flux but reducing shoreface flux to $Q_{\mathrm{S}}=30 \mathrm{~m}^{3} \mathrm{~m}^{-1} \mathrm{yr}^{-1}$, the barrier enters a transitional mode of transgressive behavior. Initially, the greater imbalance in flux partitioning results in erosion of the shoreline, with scarping failing to fully compensate for volume losses at the beach or shoreface. However, scarping allows for transient periods of beach recovery, followed by episodes of subaerial volume accumulation. As time continues, accumulated subaerial volume becomes large enough that scarping returns greater quantities of sediment to the beach or shoreface, slowing and eventually reversing shoreline erosion to complete a transition to dune-dominated aggradation (Fig. 12b). This transition is more pronounced when the magnitudes of both $Q_{\mathrm{S}}$ and $Q_{\mathrm{D}}$ are reduced $\left(Q_{\mathrm{S}}=\right.$ $5 \mathrm{~m}^{3} \mathrm{~m}^{-1} \mathrm{yr}^{-1}$ and $\left.Q_{\mathrm{D}}=22 \mathrm{~m}^{3} \mathrm{~m}^{-1} \mathrm{yr}^{-1}\right)$, resulting in a longer period of initial scarping and landward transgression of the foredune crest (Fig. 12d).
When foredune fluxes exceed shoreface fluxes by approximately half an order of magnitude or more (we describe this as $Q_{\mathrm{D}} \gg Q_{\mathrm{S}}$ ), the behavior of the barrier becomes dominated by transgression. For positive shoreface flux values, this results in a mode of dune-dominated transgression, exemplified by the scenario of $Q_{\mathrm{S}}=23 \mathrm{~m}^{3} \mathrm{~m}^{-1} \mathrm{yr}^{-1}$ and $Q_{\mathrm{D}}=60 \mathrm{~m}^{3} \mathrm{~m}^{-1} \mathrm{yr}^{-1}$ (Fig. 12c). The flux imbalance driving this behavior is so large that any transient shoreline extension resulting from scarping is immediately reversed by rapid transfer of volume to the subaerial system. With the subaerial seaward flank unable to extend seaward, the foredune undergoes high-frequency cycles of truncation on its seaward margin and volume accumulation, resulting in net landward advance. Hypothetically, this behavior could eventually result in transition to aggradation if the subaerial system becomes increasingly enlarged, resulting in scarping events sufficiently voluminous to slow shoreline retreat. However, as subaerial growth slows with time owing to a decrease in the ratio of accumulation surface to cross-sectional volume, the time horizon necessary to achieve relative "stability" greatly exceeds the 500-year time horizon of our modeling exercises. 


\section{Discussion}

The results of our modeling exercises suggest that a twostep partitioning in sediment fluxes to barriers could explain many of the morphologies and behaviors observed in nature. It is of note that our framework appears to simulate some understudied morphologies and behaviors, including dunedominated transgression (arising when $Q_{\mathrm{S}}<Q_{\mathrm{D}}$ ) and crossshore amalgamation. Further, we find that our model captures the magnitude of mesoscale changes in moving boundaries (e.g., shoreline) observed and inferred for real-world barriers. We discuss the response of the barrier in terms of the predominant allogenic drivers in our model (SLR and shoreface sediment fluxes), as well as highlight the implications of flux partitioning ( $Q_{\mathrm{S}}$ vs. $\left.Q_{\mathrm{D}}\right)$, with particular attention given to dune dominance $\left(Q_{\mathrm{S}}<Q_{\mathrm{D}}\right)$.

\subsection{Sediment availability and relative sea-level rise}

Our modeling results demonstrate that the response of barriers to changing rates of SLR and shoreface sediment fluxes $\left(Q_{S}\right)$ are nonlinear. While increasing SLR (up to $20 \mathrm{~mm} \mathrm{yr}^{-1}$ ) generally results in a state shift towards more transgressive behavior, state shifts occur extremely rapidly across a relatively limited range of specific shoreface sediment flux thresholds ( $\sim 0$ to $33 \mathrm{~m}^{3} \mathrm{~m}^{-1} \mathrm{yr}^{-1}$; Fig. 9). The effect is that changes in barrier sediment availability may be more important than SLR in dictating how behavior and morphology will change over the mesoscale. This has implications for studies of shoreline change that rely solely on SLR and mathematical relationships to model shoreline migration over decadal to centennial scales. For instance, Vousdoukas et al. (2020) projected future rates of global sandy shoreline retreat using a model based on the principles of the Bruun rule, utilizing sea-level rise rates estimated from the Intergovernmental Panel on Climate Change's RCP4.5 and RCP8.5 scenarios. Subsequent probabilistic modeling of shoreline retreat showed that $13.6 \%$ to $15.2 \%$ of global sandy coasts would retreat more than $100 \mathrm{~m}$ by the year 2050 , with $35.7 \%$ to $49.5 \%$ of coasts severely eroded by the year 2100. Taking into account modern beach widths, the authors posited that close to half of all sandy beaches could be "extinct" by the start of the 22nd century. However, as highlighted by Cooper et al. (2020), it is worth noting that this approach assumes a constant sediment supply and a relative lack of cross-shore and alongshore sediment transport pathways. Significant departures from predicted shoreline geometries could occur along shorelines where human coastal intervention, natural lags in alongshore sediment transport, and variations in SLR (due to uneven and accelerating global sea-level rise) combine to alter sediment fluxes to the beach. In addition to assuming a constant sediment supply, Vousdoukas et al. (2020) also note that their work does not examine the availability of horizontal and vertical accommodation for beaches to migrate. Both considerations impact our model results significantly, and the ability for a coupled beach-dune system to migrate vertically and horizontally is certainly beneficial for system longevity. For example, our modeled barrier persists for over a century at rates of sea-level rise more than double the present-day global sealevel rise rate of $3.3 \mathrm{~mm} \mathrm{yr}^{-1}$, including in cases of moderately negative sediment input (Fig. 13). This suggests natural beaches can keep up with accelerated sea-level rise over centennial timescales, but with the potential for substantial horizontal translation and/or coincident barrier narrowing.

Additional factors that may buffer the potential loss of natural beaches include preexisting dune volume and island width. Wide barriers in particular can provide space for subaerial accumulation and a glut of sediment to directly counter erosion caused by sand deficits and increasing SLR. This is exemplified by formerly and presently wide barrier islands such as Cedar and Parramore islands in Virginia both of which were historically around 4 times wider than the $400 \mathrm{~m}$ wide barrier initialized in our model investigation. Despite experiencing an acceleration in relative SLR of 3 to $4 \mathrm{~mm} \mathrm{yr}^{-1}$ over the last century (Boon and Mitchell, 2015), these islands have recently or historically sustained kilometer-scale landward shoreline migration over decadal to centennial timescales (McBride et al., 2015; Deaton et al., 2017; Shawler et al., 2019). Similar longer-term and sustained narrowing of previously wide barriers has also been inferred at Bogue Banks, North Carolina, a system of formerly progradational islands that began to undergo net shoreline erosion at approximately $1 \mathrm{ka}$ (Timmons et al., 2010). The combination of our modeling results and observations from natural systems therefore suggest that net sand surpluses over geological to historical timescales that serve to enhance system volume storage may render barriers more resistant to periods of sediment deficit or accelerated SLR, particularly over the mesoscale.

In contrast to natural systems, the resistance afforded by historical sediment fluxes may not exist for built systems, in which human development effectively removes volume and space that could otherwise be used to buffer the impacts of erosion and increasing accommodation from SLR. For example, in most developed stretches of the New Jersey coast, natural dunes no longer exist, replaced with relatively low, artificial dunes that provide little volume storage (Nordstrom and Arens, 1998). Human construction of dunes and other infrastructure can also block transport of sediment to foredunes and other parts of the subaerial barrier surface (Miselis et al., 2016; Rogers et al., 2015; Costas et al., 2006), preventing the accumulation of new volume in the barrier interior that could later be available to buffer future shoreline erosion. Given that our results show that major barrier state changes occur over a relatively narrow range of shoreface sediment fluxes, we posit that development-related disruptions in sediment availability are likely to combine with enhanced SLR to promote rates of shoreline migration that exceed the vari- 

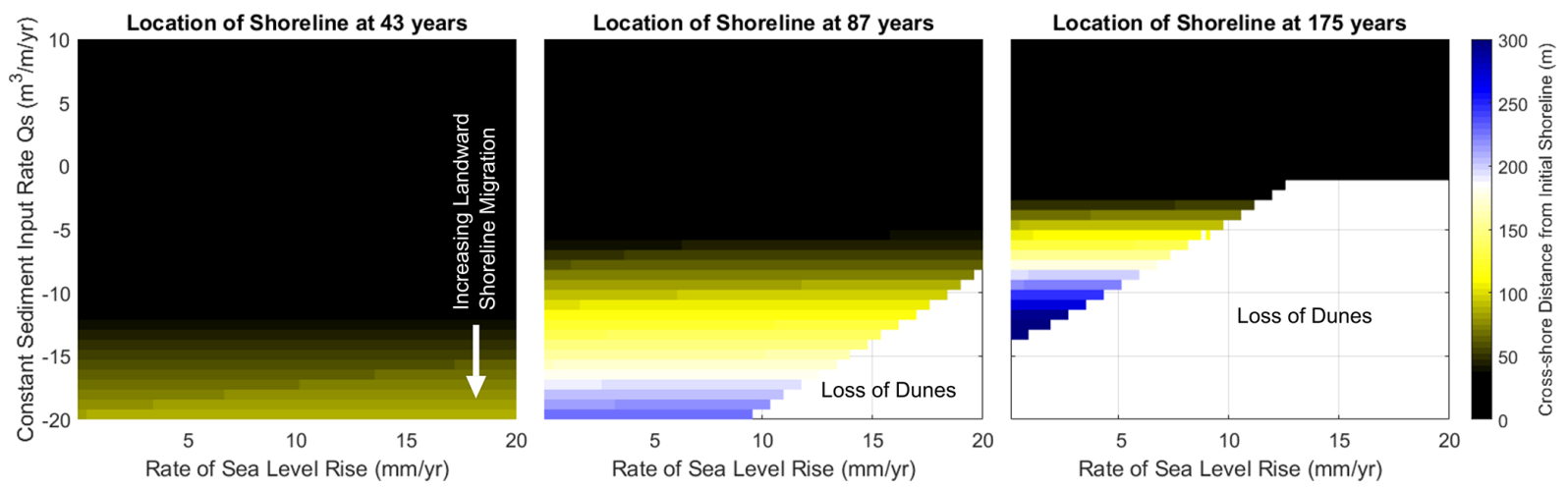

Figure 13. Plots of shoreline location $x_{\mathrm{S}}$ for a simulated barrier experiencing $Q_{\mathrm{S}}$ in the range of -20 to $10 \mathrm{~m}^{3} \mathrm{~m}^{-1} \mathrm{yr}^{-1} \mathrm{over}$ time steps of 32, 87, and 175 years. Regions with no data correspond with complete destruction of the barrier's subaerial superstructure (loss of dunes). Note that deepest black shade represents a distance to the initial shoreline of $\leq 0 \mathrm{~m}$. $Q_{\mathrm{S}}$ represents shoreface flux.

ability of geological and historical records over decadal to centennial scales.

Discounting human development, Psuty and Silveira (2010) note that individual barriers experiencing changes in SLR could also experience lags in alongshore response, complicating our cross-shore-focused approach and that of Vousdoukas et al. (2020). Typically, downdrift beaches tend to be accretional and updrift beaches erosional, with an intervening point of relative stability and equilibrium (Psuty and Silveira, 2010). Such a gradient is reflected in barriers such as the Assateague and Fire islands, in which downdrift spit ends function as sediment sinks for eroding updrift beaches (Fig. 14). As sea level rises, applying a landward forcing in sediment-starved reaches, the point of equilibrium should translate downdrift (Psuty, 2008; Davidson-Arnott, 2005). This could result in updrift areas experiencing increasing erosion, while transient enhancement of progradation occurs in distal downdrift reaches (Psuty and Silveira, 2010). The lag in response from updrift to downdrift may trigger an island-wide transition to a rotational mode of barrier displacement, which is common in many barrier islands around the world (Fitzgerald et al., 1984). We anticipate that coupling our cross-shore model in the alongshore could capture this downdrift-cascading behavior, allowing us to estimate how and when it will affect changes on modern barriers. In the interim, however, the current cross-shore approach allows us to conservatively simulate the baseline behaviors that could arise in the absence of alongshore-propagating variations in shoreface flux mediated by increasing rate of SLR.

\subsection{Dune-dominated transgression}

The investigation of the competition between shoreface $\left(Q_{\mathrm{S}}\right)$ and foredune $\left(Q_{\mathrm{D}}\right)$ fluxes expands the earlier work of Ciarletta et al. (2019b), which mostly examined cases where $Q_{\mathrm{S}}$ was moderately larger than $Q_{\mathrm{D}}$. When $Q_{\mathrm{S}}$ greatly exceeds $Q_{\mathrm{D}}$, the morphology of barriers is dominated by mul- tiple, prograding, low-relief dune ridges. As the magnitude of $Q_{\mathrm{S}}$ approaches $Q_{\mathrm{D}}$, the morphology of the barrier superstructure becomes increasingly dominated by a large, singular foredune or (as our new results demonstrate) cross-shore amalgamation of dunes through time. When $Q_{\mathrm{S}}<Q_{\mathrm{D}}$, our modeling suggests the barrier is subject to complex state shifts through different modes of dune-dominated aggradation and transgression, where barrier volume is preferentially stored in the subaerial superstructure as opposed to the subaqueous substructure.

The southern Santa Catarina coast of Brazil presents qualitative examples of all $Q_{\mathrm{S}}$ vs. $Q_{\mathrm{D}}$ conditions presented in our model (Rodrigues et al., 2020). Here, a progradational, mainland-attached beach- and foredune-ridge plain ("strandplain") is backed by a succession of large, transgressive dune ridges and dune fields, in which the volume of subaerial sand (stored in the form of relict or stabilized dune systems) corresponds not only with the past rate and direction of shoreline migration (function of $Q_{\mathrm{s}}$ ) but also the inferred magnitude of past wind-driven flux (a primary driver of $Q_{\mathrm{D}}$ ). Specifically, Rodrigues et al. (2020) describe periods of sustained beach progradation, thought to be coincident with wet periods of enhanced fluvial discharge to the coast, as consuming sand volume that would otherwise be sent to dunes, much like in the $Q_{\mathrm{S}}>Q_{\mathrm{D}}$ scenario in the model. In contrast, conditions in which $Q_{\mathrm{S}}<Q_{\mathrm{D}}$ are thought to have occurred at Santa Catarina during the Little Ice Age, recorded by an episode during which beach ridges transformed into aeolian foredunes or blowouts as the climate dried and became windier. This episode is likely coincident with shoreline transgression (Guedes et al., 2011). Intriguingly, these inferences about system behavior during the Little Ice Age suggest not only that $Q_{\mathrm{S}}$ is variable in relation to $Q_{\mathrm{D}}$ but also that $Q_{\mathrm{D}}$ may be further enhanced during episodes of climate-mediated low $Q_{\mathrm{S}}$, creating a feedback to drive the system towards dune dominance. 


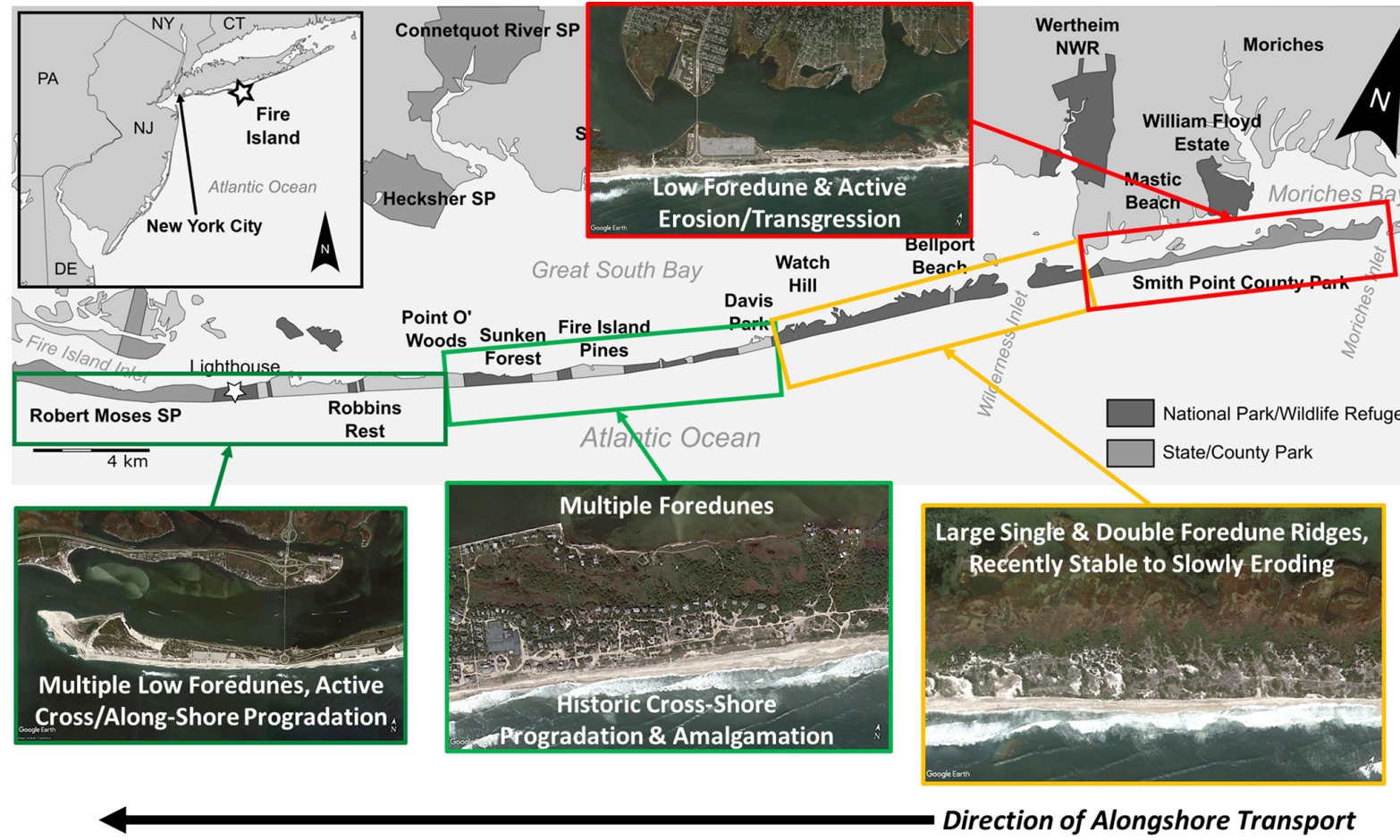

Figure 14. Overview of Fire Island alongshore sediment transport gradient, with the updrift (eastern) end of the island displaying low, overwashed transgressive morphology and downdrift (western) end of island showing multiple beach ridges and a spit extension typical of distal accretion. The inset shows the location of Fire Island within the coastal Mid-Atlantic US region. Green outlines correspond to regions characterized by present and/or historical progradation and cross-shore amalgamation, yellow outlines correspond to those characterized by aggradation or slow erosion, and red outlines correspond to those characterized by erosion or migration. Map data (C) Google Earth, Landsat/Copernicus 2019.

While changes in flux partitioning $\left(Q_{\mathrm{S}}\right.$ vs. $\left.Q_{\mathrm{D}}\right)$ can be observed in cross-shore morphology at places like Santa Catarina, it is also possible to observe alongshore gradients in dune dominance associated with sediment availability within individual modern barriers, with shifts from transgressive dune-dominated morphologies (updrift) to progradational beaches with multiple low-relief ridges (downdrift). To the first order, this suggests that our model is capturing the details of a more complex morphological response spectrum than was recognized by Psuty and Silveira (2010) but hinted at by others. Model results show that at rates of SLR $<5 \mathrm{~mm} \mathrm{yr}^{-1}$ and given reasonable $Q_{\mathrm{S}}$ values ( -10 to $40 \mathrm{~m}^{3} \mathrm{~m}^{-1} \mathrm{yr}^{-1}$; Ciarletta et al., 2019b), six different morphological states are possible, including dunedominated transgression. This level of morphological complexity is found, for example, within the tombolo barrier connecting the twin bedrock cores of Miquelon-Langlade (France) off the southern coast of Newfoundland. Transgressive, parabolic dunes 15-20 m high ("Les Butteraux") characterize its northern end and, continuing southward, transition into a short stretch of large, linear dunes and then into a set of relatively small progradational ridges (Billy et al., 2013, 2014). The morphological gradient mirrors the local alongshore transport regime (updrift erosional and downdrift depositional) observed on Fire Island, New York, but offers an alternate, dune-dominated example (Fig. 14).

We note that our model-field comparison is complicated by sites where our model framework suggests the $Q_{\mathrm{S}}<Q_{\mathrm{D}}$ relationship could create large, transgressive dune morphologies, but no such dunes are present. This may be due to significant aeolian deflation, which, though not captured in the SBSP model, we view as another important flux shaping barrier landscapes. A modern example of such deflationmediated morphology exists in the bedrock-grounded barriers of the Outer Hebrides, Scotland (Cooper et al., 2012). Sediment within this "wind-dominated" (cf. Pile et al., 2019) barrier system is largely stored in thin, landward-stretching sheets of windblown sand up to $2 \mathrm{~km}$ wide (locally referred to as "machair"). The lack of large dunes in this system is ascribed to a dearth of suitable trapping vegetation, as well as insufficient sediment delivery to offset landward deflation on transiently developed foredunes (Pile et al., 2019). This suggests the Outer Hebrides system could represent a further transgressive end-member evolving under a three-step partitioning model of fluxes, which includes not just fluxes from shoreface to beach $\left(Q_{\mathrm{S}}\right)$ and from beach to dune $\left(Q_{\mathrm{D}}\right)$ but also dune-to-machair fluxes (wind-driven deflation, $Q_{\mathrm{W}}$ ). Such a tripartite system is certain to have feedbacks on bar- 
rier response that exceed the scope of the current work, although it is tempting to speculate that such partitioning could allow barriers to respond more rapidly and less destructively to increasing SLR than our modeled system.

Finally, our model does not consider vegetation feedbacks, which previous modeling by Durán Vinent and Moore (2013) suggests may alter the shape of the dunes and dunefields formed by aeolian action. Specifically, these authors note that stronger vegetative forcing results in more linear, stable dunes, while sparse vegetation creates transgressive dunefields or in some cases sand sheets (Kasse, 1997; Pile et al., 2019). Intriguingly, Mendes and Giannini (2015), studying the same section of the Santa Catarina coast as Rodrigues et al. (2020), posit that stabilization of dunes is tied to coincident increases in precipitation and decreases in windiness, which also suggests an inverse relationship between vegetation growth and $Q_{\mathrm{D}}$ in natural systems. This relationship may enhance the morphological impacts of the inverse relationship between $Q_{\mathrm{S}}$ and $Q_{\mathrm{D}}$ implied by Rodrigues et al. (2020), suggesting that, at least on centennial scales, climate (via impacts to vegetation and land cover) is a major driver of barrier and beach behavior. Such a hypothesis is supported by the work of Jackson et al. (2019), who found that synchronous dune transgression and coastal erosion occurred in Europe during the Little Ice Age as a function of combined climate-mediated vegetation dieback, increasing windiness (due to increased storminess), and enhanced aeolian flux. Multiple systems of large, transgressive dunes in the USA, such as the Savage Neck Dunes in Virginia (Davis, 2020), were similarly active during the Little Ice Age (Havholm et al., 2004), potentially signifying a global expansion of dune-dominated coastal systems into the midlatitudes during that time. In the context of modern climate change, this relationship between vegetation and $Q_{\mathrm{S}}-Q_{\mathrm{D}}$ partitioning suggests relatively high-latitude present-day barriers (e.g., those at Miquelon-Langlade) could be subjected to decreasing dune dominance in the future, since the formative climatic conditions that led to dune accretion may no longer exist. We posit that as subaerial morphology becomes relict, erosion of the barrier superstructure could result in an irreversible state transition that gradually enhances system vulnerability to increasing SLR and decreasing sediment availability. In future study, this hypothesis could be investigated in an expanded framework that considers barrier sensitivity to changes in $Q_{\mathrm{W}}$. Specifically, Jackson et al. (2019) describes a model of coastal dune behavior effectively driven by $Q_{\mathrm{S}}$ and $Q_{\mathrm{W}}$ that could be combined with our numerical implementation of the Psuty (2008) conceptual model $\left(Q_{\mathrm{S}}\right.$ and $\left.Q_{\mathrm{D}}\right)$ to construct a quantitative multi-flux framework $\left(Q_{\mathrm{S}}, Q_{\mathrm{D}}\right.$, and $\left.Q_{\mathrm{W}}\right)$.

\subsection{Sandy-substructure accommodation}

Our model framework allows us to vary the depth of the barrier substructure or its sandy platform thickness to explore how it is affected by both sediment fluxes and an increasing rate of SLR. Specifically, we showed that decreasing the substructure depth from 5 to $2.5 \mathrm{~m}$ increases barrier sensitivity to morphologic state shifts, as decreased vertical accommodation increases the corresponding horizontal shoreline response (see Figs. 9 and 11). This relationship also enables some unexpected behaviors, especially as it relates to dunedominated transgression. Under conditions of limited substructure depth, material eroded from dunes rapidly replenishes the beach, allowing beach-to-dune fluxes to persist even as the shoreline undergoes overall retreat (e.g., Fig. 11c). The enhanced sensitivity to state shifts can be observed in the number of input parameter combinations ( $Q_{\mathrm{s}}$ and SLR) that result in amalgamative behaviors. Relative to $D_{\mathrm{T}}=5 \mathrm{~m}$, the shallower $D_{\mathrm{T}}=2.5 \mathrm{~m}$ expands the number of input combinations where strictly progradation or aggradation and transgression are possible, reducing the extent of the amalgamative "buffer" between the two end-member states. We also note that with decreased $D_{\mathrm{T}}$, the destructive transgressive regime is slightly expanded, particularly at slower rates of SLR $\left(<5 \mathrm{~mm} \mathrm{yr}^{-1}\right)$. This occurs because even slightly negative fluxes result in greater horizontal (e.g., landward) shoreline displacement than would occur with a deeper substructure.

Based on the results of our investigations, which do not account for cross-shore energetics, a possible consequence of shallower substructure depth is that alongshore sediment delivery could become the dominant mechanism influencing barrier states. In real-world barriers, there is likely a degree of similarity in the concept of a sandy substructure depth and the inner depth of closure, which is defined as the seaward limit of the "littoral zone" (Hallermeier, 1981). While the latter is a cross-shore construct based on wave energy, Hallermeier (1978) describes the littoral zone as being significantly shaped by alongshore transport, a process which at least one study has shown can cause upper-shoreface profiles to depart significantly from cross-shore equilibrium predicted by the Bruun rule (List et al., 1997). Similarly, historical and geological investigations indicate that barriers subjected to kilometer-scale shoreline movement over multidecadal timescales are strongly influenced by spatiotemporal variations in alongshore sediment delivery (Brooke et al., 2008; Lindhorst et al., 2010; Oliver et al., 2017; Raff et al., 2018; Shawler et al., 2019).

An example of this influence is provided by the barrier islands along the western central Florida coast, which are described as being not only extremely dynamic but also alongshore-transport dominated (Davis et al., 2003; Davis and Barnard, 2003). With vertical accommodation limited by bedrock and scarce offshore sediment reservoirs (limiting cross-shore transport contributions), variations in alongshore sediment redistribution can lead to pronounced changes in coastal geography and morphological state over sub-centennial scales. Combining our model results with observations from places like western central Florida, we pro- 
pose that barrier systems with limited vertical accommodation could make ideal laboratories to study the morphological impacts of changes in sediment input and SLR over relatively short timescales, potentially predicting the magnitude of future changes in systems with slower responses. That said, we recognize that direct comparison between sites with different $D_{\mathrm{T}}$ could be hindered by varying ratios of shoreface and dune fluxes or more complex regimes, in which aeolian deflation represents a significant loss. Consequently, a more accurate comparison might be drawn between barriers with different $D_{\mathrm{T}}$ that exist at similar latitudes, because, as the work of Rodrigues et al. (2020) shows, subaerial fluxes are influenced by regional-scale climate variability.

\section{Conclusions and implications}

Our model investigations, coupled with historical and modern observations of real-world barriers, highlight the importance of sediment delivery and partitioning within coastal systems in driving their mesoscale behavior. Over the scale of decades to centuries, changes in direction and magnitude of sediment transport can cause the seaward and landward limits of barriers - as well as their subaerial height and topographic complexity - to vary on the order of meters to kilometers. Among other outcomes, variations in sediment delivery and partitioning are expected to cause significant departures from shoreface equilibrium retreat geometries, suggesting that mathematical relationships defining rates of shoreline retreat as a function of rate of sea-level rise (and underlying shelf slope) are extremely restrictive at this timescale especially if attempting to predict changes in subaerial morphology and resulting ecology.

Specifically, with our two-step partitioning approach, we demonstrate and infer the following conclusions.

1. Modeled barriers respond nonlinearly to changes in SLR (up to $20 \mathrm{~mm} \mathrm{yr}^{-1}$ ), although variations in sediment availability play a much more significant role in driving morphological shifts over the mesoscale. Our framework also captures several behaviors that are not readily described by the classic progradation, aggradation, and transgression states, including amalgamation and dune-dominated aggradation and transgression.

2. Dune dominance in our modeled barrier can lead to a complex array of behaviors. Over decadal to centennial scales, dune-dominated barriers can be either aggradational or transgressive, or may exist in a notable transitional state. During dune-dominated transgression, the subaerial volume of the barrier can be continually inflated despite landward retreat of the shoreline. This process is driven by a recycling of sediment scarped from the dune back into the beach, where it can be subsequently repartitioned back to the subaerial portion of the system.
3. Decreased vertical accommodation to extend or erode the sandy substructure of the barrier increases the sensitivity of the system to both increasing SLR and changes in sediment delivery and partitioning. This enhanced sensitivity manifests in both progradational and transgressive responses, including under conditions of dune dominance. Because barriers with limited vertical accommodation respond rapidly to external forcing, we propose that they could offer ideal natural laboratories to study the effects of changing SLR or sediment delivery over sub-decadal and sub-centennial timescales.

Importantly, our work does not fully consider the impacts of aeolian transport, event-scale overwash, or vegetation, any of which could enhance or decrease the resistance of the barrier structure to changes in sediment delivery, as well as alter the partitioning of sediment in the cross-shore (e.g., plants increasing subaerial sediment trapping efficiency or overwash involving both landward- and seaward-directed sediment transport components). This effort does, however, suggest that modeling morphologic change based on timevariable sediment input could be key to resolving the baseline state of barrier systems, especially those impacted by anthropogenic sediment interventions (e.g., nourishment, groins). Alternatively, from an ecological perspective, this could help inform management by refining understanding of a system's natural resistance to change or the range of sediment flux variation and partitioning that can be accommodated without crossing a state threshold.

Although we do not account for all potential flux partitioning, our model results agree with the magnitude and timescale of changes in barrier morphology observed along the US East Coast, suggesting that meter- to kilometer-scale migration of horizontal cross-shore boundaries within barriers occurs readily as a function of mesoscale variation in sediment availability. These changes are sufficiently large to obscure the signals of long-term retreat trends over decadal to centennial timescales, and they illustrate the challenge of applying geometric relationships to predict, for instance, shoreline movement as a function of increasing sea level alone. However, by examining relict geomorphology and historical changes in shoreline geometry, it may be possible to infer the magnitude of past changes in sediment delivery, as well as estimate differences in the flux partitioning between the subaqueous and subaerial barrier components. Coupling this approach with cross-shore and alongshore geomorphological observations from field and remote sensing efforts may ultimately allow quantitative exploration of barrier- and regional-scale sediment flux gradients over decadal to centennial timescales. Additionally, we hypothesize that this approach could prove valuable to interpreting millennial-scale records of sediment delivery and accommodation changes preserved in the stratigraphy of long-lived beach-ridge plain systems, where our model could be applied to shorter (sub- 
millennial) time intervals to reconstruct system evolution in a piecewise manner.

Code availability. The model code used in these investigations is available as part of an accompanying USGS software release (https://doi.org/10.5066/P9DE6QCL; Ciarletta et al., 2020).

Data availability. Example model data outputs generated during this study are available as part of the aforementioned USGS software release.

Author contributions. DJC conceived the model experiments, planned the investigations with JLM, carried out the simulations, and took the lead in writing the manuscript with critical feedback from JLS and CJH.

Competing interests. The authors declare no competing interests.

Acknowledgements. This paper benefited from constructive evaluations by Eli Lazarus and an anonymous referee. We would also like to acknowledge our colleagues in the USGS St. Petersburg Coastal Sediment Availability and Flux (CSAF) group for their continued support and feedback: Julie Bernier, Noreen Buster, Arnell Forde, Tim Nelson, and Emily Wei. Any use of trade, firm, or product names is for descriptive purposes only and does not imply endorsement by the US Government.

Financial support. This work made possible through the USGS Mendenhall Research Fellowship program and the USGS Coastal and Marine Geology program. Federal funds under National Oceanic and Atmospheric Administration (NOAA) award no. NA18OAR4170083, Virginia Sea Grant College Program project no. 721557 , the NOAA National Sea Grant College Program, and US Department of Commerce supported Justin L. Shawler. The statements, findings, conclusions, and recommendations are those of the authors and do not necessarily reflect the views of NOAA or the US Department of Commerce. This paper is contribution no. 3989 of the Virginia Institute of Marine Science, William \& Mary.

Review statement. This paper was edited by Orencio Duran Vinent and reviewed by Eli D. Lazarus and one anonymous referee.

\section{References}

Aagaard, T., Davidson-Arnott, R., Greenwood, B., and Nielsen, J.: Sediment supply from shoreface to dunes: linking sediment transport measurements and long-term morphological evolution, Geomorphology, 60, 205-224, 2004.

Ashton, A. D. and Lorenzo-Trueba, J.: Morphodynamics of barrier response to sea-level rise, in: Barrier Dynamics and Response to Changing Climate, Springer, Cham, 277-304, 2018.

Billy, J., Robin, N., Certain, R., Hein, C., and Berné, S.: Barrier shoreline evolution constrained by shoreface sediment reservoir and substrate control: The Miquelon-Langlade Barrier, NW Atlantic, J. Coast. Res., 65, 2089-2094, 2013.

Billy, J., Robin, N., Hein, C. J., Certain, R., and FitzGerald, D. M.: Internal architecture of mixed sand-and-gravel beach ridges: Miquelon-Langlade Barrier, NW Atlantic, Mar. Geol., 357, 5371,2014

Boon, J. D. and Mitchell, M.: Nonlinear change in sea level observed at North American tide stations, J. Coast. Res., 31, 12951305, 2015.

Brenner, O. T., Moore, L. J., and Murray, A. B.: The complex influences of back-barrier deposition, substrate slope and underlying stratigraphy in barrier island response to sea-level rise: Insights from the Virginia Barrier Islands, Mid-Atlantic Bight, USA, Geomorphology, 246, 334-350, 2015.

Bristow, C. S. and Pucillo, K.: Quantifying rates of coastal progradation from sediment volume using GPR and OSL: the Holocene fill of Guichen Bay, south-east South Australia, Sedimentology, 53, 769-788, 2006.

Brooke, B., Lee, R., Cox, M., Olley, J., and Pietsch, T.: Rates of shoreline progradation during the last 1700 years at Beachmere, Southeastern Queensland, Australia, based on optically stimulated luminescence dating of beach ridges, J. Coast. Res., 24, 640-648, 2008.

Ciarletta, D. J., Lorenzo-Trueba, J., and Ashton, A.: Interaction of Sea-Level Pulses with Periodically Retreating Barrier Islands, Front. Earth Sci., 7, 279, https://doi.org/10.3389/feart.2019.00279, 2019a.

Ciarletta, D. J., Shawler, J. L., Tenebruso, C., Hein, C. J., and Lorenzo-Trueba, J.: Reconstructing coastal sediment budgets from beach- and foredune- ridge morphology: A coupled field and modeling approach, J. Geophys. Res.-Earth, 124, 13981416, $2019 b$.

Ciarletta, D. J., Miselis, J. L., Shawler, J. L., and Hein C. J.: Subaerial Barrier Sediment Partitioning (SBSP) Model Version 1.0, US Geological Survey software release, https://doi.org/10.5066/P9DE6QCL, 2020.

Cohn, N., Ruggiero, P., García-Medina, G., Anderson, D., Serafin, K. A., and Biel, R.: Environmental and morphologic controls on wave-induced dune response, Geomorphology, 329, 108-128, 2019.

Cooper, J. A. G., Jackson, D. W. T., Dawson, A. G., Dawson, S., Bates, C. R., and Ritchie, W.: Barrier islands on bedrock: A new landform type demonstrating the role of antecedent topography on barrier form and evolution, Geology, 40, 923-926, 2012.

Cooper, J. A. G., Green, A. N., and Loureiro, C.: Geological constraints on mesoscale coastal barrier behavior, Global Planet Change, 168, 15-34, 2018. 
Cooper, A., Masselink, G., Coco, G., Short, A., Castelle, B., Rogers, K., Anthony, E., Green, A., Kelley, J., Pilkey, O., and Jackson, D.: Sandy beaches can survive sea-level rise, EarthArXiv [preprint], https://doi.org/10.31223/osf.io/4md6e, 2020.

Costas, S., Alejo, I., and Nombela, M. A.: Sand barrier behavior under man-induced inlet relocation, J. Coast. Res., 39, 428-432, 2006.

Davidson-Arnott, R. G.: Conceptual model of the effects of sea level rise on sandy coasts, J. Coast. Res., 21, 1166-1172, 2005.

Davidson-Arnott, R., Hesp, P., Ollerhead, J., Walker, I., Bauer, B., Delgado-Fernandez, I., and Smyth, T.: Sediment budget controls on foredune height: Comparing simulation model results with field data, Earth Surf. Proc. Land., 43, 1798-1810, 2018.

Davis, E. H.: A Reassessment of the Late Quaternary Surficial Geology of the Lower Delmarva Peninsula, Virginia, MS thesis, University of Delaware, Delaware, 2020.

Davis Jr., R. A. and Barnard, P.: Morphodynamics of the barrierinlet system, west-central Florida, Mar. Geol., 200, 77-101, 2003.

Davis Jr., R. A., Yale, K. E., Pekala, J. M., and Hamilton, M. V.: Barrier island stratigraphy and Holocene history of west-central Florida, Mar. Geol., 200, 103-123, 2003.

Deaton, C. D., Hein, C. J., and Kirwan, M. L.: Barrier island migration dominates ecogeomorphic feedbacks and drives salt marsh loss along the Virginia Atlantic Coast, USA, Geology, 45, 123126, 2017.

Dillenburg, S. R., Tomazelli, L. J., Hesp, P. A., Barboza, E. G., Clerot, L. C. P., and Silva, D. D.: Stratigraphy and evolution of a prograded transgressive dunefield barrier in southern Brazil, J. Coast. Res., 39, 132-135, 2006.

Durán Vinent, O. and Moore, L. J.: Vegetation controls on the maximum size of coastal dunes, P. Natl. Acad. Sci. USA, 110, 17-217, 2013.

Fitzgerald, D. M., Penland, S., and Nummedal, D. A. G.: Control of barrier island shape by inlet sediment bypassing: East Frisian Islands, West Germany, Mar. Geol., 60, 355-376, 1984.

French, J., Payo, A., Murray, B., Orford, J., Eliot, M., and Cowell, P.: Appropriate complexity for the prediction of coastal and estuarine geomorphic behaviour at decadal to centennial scales, Geomorphology, 256, 3-16, 2016.

Guedes, C. C. F., Giannini, P. C. F., Sawakuchi, A. O., DeWitt, R., Nascimento Jr., D. R., Aguiar, V. A. P., and Rossi, M. G.: Determination of controls on Holocene barrier progradation through application of OSL dating: The Ilha Comprida Barrier example, Southeastern Brazil, Mar. Geol., 285, 1-16, 2011.

Hallermeier, R. J.: Uses for a calculated limit depth to beach erosion, in: Proceedings of 16th Coastal Engineering Conference, American Society of Civil Engineers, Hamburg, Germany, 14931512,1978 .

Hallermeier, R. J.: Seaward limit of significant sand transport by waves: an annual zonation for seasonal profiles (No. CERCCETA-81-2), Army Corps, Coastal Engineering Research Center, Fort Belvoir, Virginia, USA, 1981.

Halsey, S. D.: Late Quaternary geologic history and morphologic development of the barrier island system along the Delmarva Peninsula of the mid-Atlantic Bight, Doctoral dissertation, University of Delaware, Delaware, 1978.

Havholm, K. G., Ames, D. V., Whittecar, G. R., Wenell, B. A., Riggs, S. R., Jol, H. M., Berger, G. W., and Holmes, M. A.:
Stratigraphy of back-barrier coastal dunes, northern North Carolina and southern Virginia, J. Coast. Res., 20, 980-999, 2004.

Hein, C. J., FitzGerald, D. M., de Souza, L. H., Georgiou, I. Y., Buynevich, I. V., Klein, A. H. da F., Thadeu de Menezes, J., Cleary, W. J., and Scolaro, T. L.: Complex coastal change in response to autogenic basin infilling: An example from a subtropical Holocene strandplain, Sedimentology, 63, 1362-1395, 2016.

Hein, C. J., Shawler, J. L., De Camargo, J. M., da Klein, A. H. F., Tenebruso, C., and Fenster, M. S.: The role of coastal sediment sinks in modifying longshore sand fluxes: examples from the coasts of southern Brazil and the mid-Atlantic, USA, in: The Proceedings of the Coastal Sediments, 27-31 May 2019, Tampa/St. Petersburg, Florida, USA, 2019.

Hesp, P. A., Giannini, P. C., Martinho, C. T., Da Silva, G. M., and Neto, N. E. A.: The Holocene barrier systems of the Santa Catarina coast, southern Brazil, in: Geology and geomorphology of Holocene coastal barriers of Brazil, Springer, Berlin, Heidelberg, 93-133, 2009.

Himmelstoss, E. A., Kratzmann, M. G., and Thieler, E. R.: National assessment of shoreline change - Summary statistics for updated vector shorelines and associated shoreline change data for the Gulf of Mexico and Southeast Atlantic coasts, US Geological Survey Open-File Report 2017-1015, US Geological Survey, Woods Hole, Massachusetts, USA, 2017.

Jackson, D. W., Costas, S., and Guisado-Pintado, E.: Large-scale transgressive coastal dune behaviour in Europe during the Little Ice Age, Global Planet. Change, 175, 82-91, 2019.

Kasse, C.: Cold-climate aeolian sand-sheet formation in northwestern Europe (c. 14-12.4 ka); a response to permafrost degradation and increased aridity, Permafrost Periglac. Process., 8, 295-311, 1997.

Kilibarda, Z. and Shillinglaw, C.: A 70 year history of coastal dune migration and beach erosion along the southern shore of Lake Michigan, Aeolian Res., 17, 263-273, 2015.

Leatherman, S. P.: Geomorphic and stratigraphic analysis of fire island, New York, Mar. Geol., 63, 173-195, 1985.

Lindhorst, S., Fuerstenau, J., Christian Hass, H., and Betzler, C.: Anatomy and sedimentary model of a hooked spit (Sylt, southern North Sea), Sedimentology, 57, 935-955, 2010.

List, J. H., Sallenger Jr, A. H., Hansen, M. E., and Jaffe, B. E.: Accelerated relative sea-level rise and rapid coastal erosion: testing a causal relationship for the Louisiana barrier islands, Mar. Geol., 140, 347-365, 1997.

Locker, S. D., Hine, A. C., Davis, R. A., Brooks, G. R., and Guy, K. K.: West-Central Florida Coastal Transect\# 1: Anclote Key, US Geological Survey Open-File Report 99-505, US Geological Survey, Woods Hole, Massachusetts, USA, 2001.

Locker, S. D., Brooks, G. R., Hine, A. C., Davis, R. A., Harrison, S. E., and Gelfenbaum, G.: West-central Florida coastal transect 2: Caladesi Island - Clearwater Beach Island, US Geological Survey Open-File Report 99-506, US Geological Survey, Woods Hole, Massachusetts, USA, 2002a.

Locker, S. D., Brooks, G. R., Hine, A. C., Davis, R. A., Harrison, S. E., and Gelfenbaum, G.: West-central Florida coastal transect 3: Sand Key, US Geological Survey Open-File Report 99507, US Geological Survey, Woods Hole, Massachusetts, USA, 2002b. 
Locker, S. D., Hine, A. C., Brooks, G. R., Davis, R. A., and Gelfenbaum, G.: West-central Florida coastal transect\# 4: Indian Rocks Beach, US Geological Survey Open-File Report 99-508, US Geological Survey, Woods Hole, Massachusetts, USA, 2002c.

Locker, S. D., Davis, R. A., Hine, A. C., Brooks, G. R., and Gelfenbaum, G.: West-central Florida coastal transect 5: Treasure Island-Long Key, US Geological Survey Open-File Report 99-509, US Geological Survey, Woods Hole, Massachusetts, USA, 2002d.

Lorenzo-Trueba, J. and Ashton, A. D.: Rollover, drowning, and discontinuous retreat: Distinct modes of barrier response to sea-level rise arising from a simple morphodynamic model, J. Geophys. Res.-Earth, 119, 779-801, https://doi.org/10.1002/2013JF002941, 2014.

Masetti, R., Fagherazzi, S., and Montanari, A.: Application of a barrier island translation model to the millennial-scale evolution of Sand Key, Florida, Cont. Shelf Res., 28, 1116-1126, 2008.

McBride, R. A., Fenster, M. S., Seminack, C. T., Richardson, T. M., Sepanik, J. M., Hanley, J. T., Bundick, J. A., and Tedder, E.: Holocene barrier-island geology and morphodynamics of the Maryland and Virginia open-ocean coasts: Fenwick, Assateague, Chincoteague, Wallops, Cedar, and Parramore Islands, in: Geological Society of America Field Guide 40, Tripping from the Fall Line: Field Excursions for the GSA Annual Meeting, Baltimore, 309-424, 2015.

McNamara, D. E. and Lazarus, E. D.: Barrier islands as coupled human-landscape systems, in: Barrier Dynamics and Response to Changing Climate, Springer, Cham, 363-383, 2018.

McNamara, D. E. and Werner, B. T.: Coupled barrier islandresort model: 1. Emergent instabilities induced by strong humanlandscape interactions, J. Geophys. Res.-Earth, 113, F01016, https://doi.org/10.1029/2007JF000840, 2008a.

McNamara, D. E. and Werner, B. T.: Coupled barrier island-resort model: 2. Tests and predictions along Ocean City and Assateague Island National Seashore, Maryland, J. Geophys. Res.-Earth, 113, F01017, https://doi.org/10.1029/2007JF000841, 2008 b.

Mendes, V. R. and Giannini, P. C. F.: Coastal dunefields of south Brazil as a record of climatic changes in the South American Monsoon System, Geomorphology, 246, 22-34, 2015.

Miselis, J. L., Andrews, B. D., Nicholson, R. S., Defne, Z., Ganju, N. K., and Navoy, A.: Evolution of mid-Atlantic coastal and back-barrier estuary environments in response to a hurricane: Implications for barrier-estuary connectivity, Estuar. Coasts, 39, 916-934, 2016.

Murray, A. B. and Moore, L. J.: Geometric constraints on long-term barrier migration: from simple to surprising, in: Barrier dynamics and response to changing climate, Springer, Cham, 211-241, 2018

Nooren, K., Hoek, W. Z., Winkels, T., Huizinga, A., Van der Plicht, H., Van Dam, R. L., Van Heteren, S., Van Bergen, M. J., Prins, M. A., Reimann, T., Wallinga, J., Cohen, K. M., Minderhoud, P., and Middelkoop, H.: The Usumacinta-Grijalva beach-ridge plain in southern Mexico: a high-resolution archive of river discharge and precipitation, Earth Surf. Dynam., 5, 529-556, https://doi.org/10.5194/esurf-5-529-2017, 2017.

Nordstrom, K. F. and Arens, S. M.: The role of human actions in evolution and management of foredunes in The Netherlands and New Jersey, USA, J. Coast. Conserv., 4, 169-180, 1998.
Oliver, T. S., Donaldson, P., Sharples, C., Roach, M., and Woodroffe, C. D.: Punctuated progradation of the Seven Mile Beach Holocene barrier system, southeastern Tasmania, Mar. Geol., 386, 76-87, 2017.

Oliver, T. S., Tamura, T., Short, A. D., and Woodroffe, C. D.: Rapid shoreline progradation followed by vertical foredune building at Pedro Beach, southeastern Australia, Earth Surf. Proc. Land., 44, 655-666, 2019.

Pile, J., Cooper, J. A. G., and Jackson, D. W. T.: Stratigraphy and internal structure of wind-dominated barrier islands (dune and machair) of the Outer Hebrides, Scotland, Earth Surf. Proc. Land., 44, 1482-1493, 2019.

Psuty, N. P.: The Coastal Foredune: A Morphological Basis for Regional Coastal Dune Development, in: Coastal Dunes: Ecology and Conservation, edited by: Martinez, M. and Psuty, N. P., Springer-Verlag, Berlin, 11-27, 2008.

Psuty, N. P. and Silveira, T. M.: Global climate change: an opportunity for coastal dunes?, J. Coast. Conserv., 14, 153-160, 2010.

Psuty, N. P. and Silveira, T. M.: Restoration of coastal foredunes, a geomorphological perspective: examples from New York and from New Jersey, USA, in: Restoration of Coastal Dunes, Springer, Berlin, Heidelberg, 33-47, 2013.

Pye, K. and Tsoar, H.: Aeolian bed forms, in: Aeolian Sand and Sand Dunes, Springer, Berlin, Heidelberg, 175-253, 2009.

Raff, J. L., Shawler, J. L., Ciarletta, D. J., Hein, E. A., LorenzoTrueba, J., and Hein, C. J.: Insights into barrier-island stability derived from transgressive/regressive state changes of Parramore Island, Virginia, Mar. Geol., 403, 1-19, 2018.

Rodrigues, F. C., Giannini, P. C., Fornari, M., and Sawakuchi, A. O.: Deglacial climate and relative sea level changes forced the shift from eolian sandsheets to dunefields in southern Brazilian coast, Geomorphology, 365, 107252, https://doi.org/10.1016/j.geomorph.2020.107252, 2020.

Rogers, L. J., Moore, L. J., Goldstein, E. B., Hein, C. J., LorenzoTrueba, J., and Ashton, A. D.: Anthropogenic controls on overwash deposition: Evidence and consequences, J. Geophys. Res.Earth, 120, 2609-2624, 2015.

Schubert, C. E.: Analysis of the shallow groundwater flow system at Fire Island National Seashore, Suffolk County, New York, US Geological Survey Scientific Investigations Report 20095259, US Geological Survey, Troy, New York, USA, 2010.

Shawler, J. L., Ciarletta, D. J., Lorenzo-Trueba, J., and Hein, C. J.: Drowned foredune ridges as evidence of pre-historical barrierisland state changes between migration and progradation, in: The Proceedings of the Coastal Sediments, St. Petersburg, Florida, USA, 158-171, 2019.

Shawler, J. L., Ciarletta, D. J., Connell, J. E., Boggs, B. Q., Hein, C. J., and Lorenzo-Trueba, J: Relative influence of antecedent topography and sea-level rise on barrier-island migration, Sedimentology, 68, 639-669, 2021.

Sherman, D. J.: Problems of scale in the modeling and interpretation of coastal dunes, Mar. Geol., 124, 339-349, 1995.

Sirkin, L. A.: Origin and history of maple bog in the Sunken Forest, Fire Island, New York, Torrey Botanical Society, Lawrence, Kansas, USA, Bulletin of the Torrey Botanical Club, 131-135, 1972.

Timmons, E. A., Rodriguez, A. B., Mattheus, C. R., and DeWitt, R.: Transition of a regressive to a transgressive barrier island due to back-barrier erosion, increased storminess, and low sediment 
supply: Bogue Banks, North Carolina, USA, Mar. Geol., 278, 100-114, 2010.

Vintem, G., Tomazelli, L. J., and Klein, A. H. da F: The effect of sand grain size in the aeolian transport processes of transgressives dunefields of the coast of the Santa Catarina State Brazil, Proceedings of the $8^{\text {th }}$ International Coastal Symposium (ICS 2004), J. Coast. Res., 39, 102-106, 2006.
Vousdoukas, M. I., Ranasinghe, R., Mentaschi, L., Plomaritis, T. A., Athanasiou, P., Luijendijk, A., and Feyen, L.: Sandy coastlines under threat of erosion, Nat. Climate Change, 10, 260-263, 2020.

Werner, B. T.: Modeling landforms as self-organized, hierarchical dynamical systems, in: Prediction in Geomorphology, Geophys. Monogr. Ser. 135, edited by: Wilcock, P. R. and Iverson, R. M., AGU, Washington, D.C., 133-150, 2003. 